RECEIVED

NOV 211995

OS.TI

\title{
Vapor Space Characterization of Waste Tank 241-C-101: Results from Samples Collected on 9/1/94
}
R. B. Lucke
T.W. Clauss
J.S. Young
M. W. Ligotke
M. McCulloch
K. H. Pool
J. S. Fruchter
B. D. McVeety
S. C. Goheen

November 1995

Prepared for Westinghouse Hanford Company under a Related Services Agreement with the U.S. Department of Energy under Contract DE-AC06-76RLO 1830

Pacific Northwest National Laboratory Operated for the U.S. Department of Energy by Battelle Memorial Institute 


\title{
DTSCLAMTER
}

This report was prepared as an account of work sponsored by an agency of the United States Government. Neither the United States Government nor any agency thereof, nor Battelle Memorial Institute. nor any of their employees, makes any warranty. exprese or implied. or asoumes any legal liability or responsibility for the accuracy. completeness, of uefulnese of any information, apparatus. product, or procese disclowed, or represente that its use would not infinge privately owned righte. Reference herein to any specific commercial product, process, or service by trade name, trademark, manufacturer, or otherwise does not necessarily constitute or imply its endorsement, recommendation, or favoring by the United States Government or any agency thereof, or Battelle Memorlal Institute. The views and opinions of authors expressed herein do not necessarily state or reflect those of the United States Government or any agency thereof.

\author{
PACIFIC NORIHWEST NATIONAL LABORATORY \\ operated by \\ BATTELLE \\ for the \\ UNITED STATES DEPARTMENT OF ENERGY \\ under Contract DE-ACO6-76RLO 1830
}

Printed In the United states of Amerien

Avalibile to DOE and por contractor from the Ofice of seientific and Technied Information, P.0. Box 62, Oal Ridge, III 578s1:

prices avalible from (610) 676-8401.

Avalibble to the public from the Fational Technical Information service, U.S. Department of Commerce, 328 Port Royal Rd., Springfield, vA 20161

This document was printed on recyeled paper. 
PNL-10491

UC-606

\section{Vapor Space Characterization of Waste Tank 241-C-101: Results from Samples Collected on 9/1/94}
R. B. Lucke
T. W. Clauss
M. W. Ligotke
K. H. Pool
B. D. McVeety
J. S. Young
M. McCulloch
J. S. Fruchter
S. C. Goheen

November 1995

Prepared for Westinghouse Hanford Company under a Related Services Agreement with the U.S. Department of Energy Contract DE-AC06-76RLO 1830

Pacific Northwest Laboratory Richland, Washington 99352 


\section{DISCLAIMER}

Portions of this document may be illegible electronic image products. Images are produced from the best available original document. 


\section{Summary}

This report describes inorganic and organic analyses results from samples obtained from the headspace of the Hanford waste storage Tank 241-C-101 (referred to as Tank C-101) and the ambient air collected near the tank. The results described here were obtained to support safety and toxicological evaluations. A summary of the results for inorganic and organic analytes is listed in Table 1. Detailed descriptions of the results appear in the text.

Quantitative results were obtained for the inorganic compounds ammonia $\left(\mathrm{NH}_{3}\right)$, nitrogen dioxide $\left(\mathrm{NO}_{2}\right)$, nitric oxide (NO), and water $\left(\mathrm{H}_{2} \mathrm{O}\right)$. Sampling for hydrogen cyanide $(\mathrm{HCN})$ and sulfur oxides $\left(\mathrm{SO}_{x}\right)$ was not requested. Organic compounds were also quantitatively determined. One hundred twelve organic tentatively identified compounds (TICs) were observed above the detection limit of (ca.) $10 \mathrm{ppbv}$, but standards for most of these were not available at the time of analysis, and the reported concentrations are semiquantitative estimates. In addition, we looked for the 40 standard TO-14 analytes. Of these, only three were observed above the 2-ppbv detection limit. The 10 organic analytes with the highest estimated concentrations are listed in Table 1 and account for approximately $58 \%$ of the total organic components in Tank C-101.

Table 1. Summary Resuits of Inorganic and Organic Samples Collected from the Headspace of Tank C-101 on 9/1/94

\begin{tabular}{llll} 
Category & Analyte & $\begin{array}{l}\text { Vapor } \\
\text { Concentration }\end{array}$ & Units \\
\cline { 3 - 4 } Inorganic & & \\
& & & \\
& $\mathrm{NH}_{3}$ & $98 \pm 1$ & $\mathrm{ppmv}$ \\
& $\mathrm{NO}_{2}$ & $\leq 0.04$ & $\mathrm{ppmv}$ \\
& $\mathrm{NO}$ & $1.5 \pm 0.1$ & $\mathrm{ppmv}$ \\
Organic & $\mathrm{H}_{2} \mathrm{O}$ & $36 \pm 1$ & $\mathrm{mg} / \mathrm{L}$ \\
& & & \\
& Dodecane & 13.61 & $\mathrm{mg} / \mathrm{m}^{3}$ \\
& Tridecane & 7.04 & $\mathrm{mg} / \mathrm{m}^{3}$ \\
& Undecane & 6.45 & $\mathrm{mg} / \mathrm{m}^{3}$ \\
& Unknown C13 Alkane & 5.70 & $\mathrm{mg} / \mathrm{m}^{3}$ \\
& Tridecane, 7-methyl- & 5.28 & $\mathrm{mg} / \mathrm{m}^{3}$ \\
& Unknown Alkene/Cycloalkane & 4.05 & $\mathrm{mg} / \mathrm{m}^{3}$ \\
& Heptane & 2.01 & $\mathrm{mg} / \mathrm{m}^{3}$ \\
& Unknown Alkene/Cycloalkane & 1.87 & $\mathrm{mg} / \mathrm{m}^{3}$ \\
& Unknown Alkyl decahydronaphthalene & 1.46 & $\mathrm{mg} / \mathrm{m}^{3}$ \\
& Decane & 1.46 & $\mathrm{mg} / \mathrm{m}^{3}$
\end{tabular}

(a) Vapor concentrations were determined using sample-volume data provided by Westinghouse Hanford Company and are based on averaged data. 

-

.

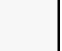

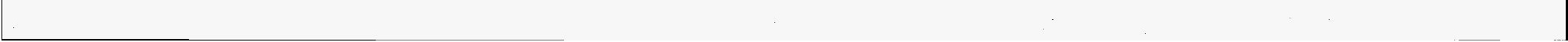

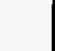




\section{Acknowledgments}

The authors gratefully acknowledge the support of other project staff at Pacific Northwest Laboratory who contributed to the successful completion of this sampling and analysis activity. Jeff Edwards served as the PNL single-point-of-contact and coordinated sample handling and communications with Westinghouse Hanford Company. K. B. Olsen assisted with the organic portion of this report. Bruce Lerner performed method development and validation work that supported the inorganic vapor sampling. Sally Slate, May-Lin Thomas, and Karen Schielke analyzed inorganic samples, and Annalisa Krupsha and Gary Dennis prepared the solid-sorbent sample trains. Brenda Thornton provided word processing support. 


\section{Abbreviations}

$\begin{array}{ll}\text { CAS } & \text { Chemical Abstracts Service } \\ \text { COC } & \text { chain of custody } \\ \text { C } & \text { concentration by volume } \\ \text { DIW } & \text { deionized water } \\ \text { emf } & \text { electromotive force } \\ \text { EPA } & \text { U.S. Environmental Protection Agency } \\ \text { GC/MS } & \text { gas chromatography/mass spectrometry } \\ \text { HP } & \text { Hewlett Packard } \\ \text { IC } & \text { ion chromatography } \\ \text { IL } & \text { impact level } \\ \text { IS } & \text { internal standard } \\ \text { MDL } & \text { minimum detection limit } \\ \text { NIST } & \text { National Institute for Standards and Technology } \\ \text { NPH } & \text { normal paraffin hydrocarbon } \\ \text { OSHA } & \text { Occupational Safety and Health Administration } \\ \text { PFA } & \text { perfluoroalkoxy } \\ \text { PNL } & \text { Pacific Northwest Laboratory } \\ \text { ppbv } & \text { part per billion by volume } \\ \text { ppmv } & \text { part per million by volume } \\ \text { QA } & \text { quality assurance } \\ \text { REL } & \text { recommended exposure limit } \\ \text { SCIC } & \text { suppressed-conductivity ion chromatography } \\ \text { SIE } & \text { selective ion electrode } \\ \text { SRM } & \text { standard reference material } \\ \text { STP } & \text { standard temperature and pressure } \\ \text { TEA } & \text { triethanolamine } \\ \text { TIC } & \text { tentatively identified compound } \\ \text { VSS } & \text { vapor sampling system } \\ \text { WHC } & \text { Westinghouse Hanford Company } \\ & \end{array}$





\section{Contents}

Summary $\ldots \ldots \ldots \ldots \ldots \ldots \ldots \ldots \ldots \ldots \ldots \ldots \ldots \ldots \ldots \ldots \ldots \ldots \ldots \ldots$

Acknowledgments $\ldots \ldots \ldots \ldots \ldots \ldots \ldots \ldots \ldots \ldots \ldots \ldots \ldots \ldots \ldots \ldots$

Abbreviations $\ldots \ldots \ldots \ldots \ldots \ldots \ldots \ldots \ldots \ldots \ldots \ldots \ldots \ldots \ldots \ldots \ldots \ldots \ldots \ldots$

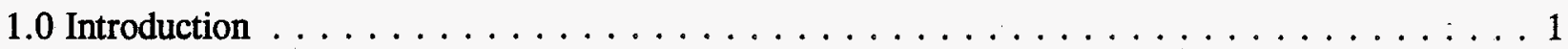

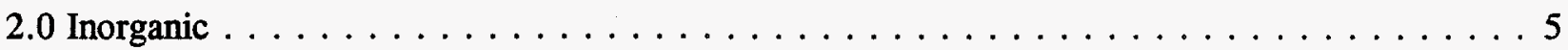

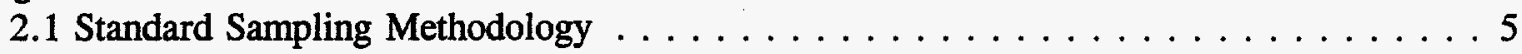

2.2 Analytical Procedures . . . . . . . . . . . . . . . . . . 6

2.3 Quality Assurance/Quality Control $\ldots \ldots \ldots \ldots \ldots \ldots \ldots \ldots \ldots$

2.4 Inorganic Sample Results . . . . . . . . . . . . . . . . . . . . . . 9

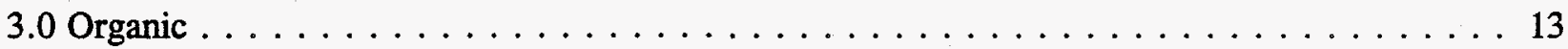

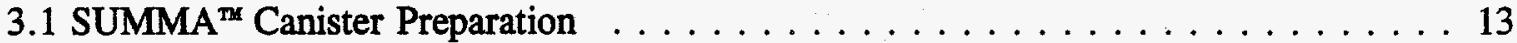

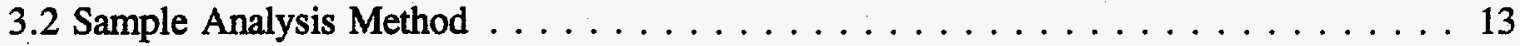

3.3 Quality Assurance/Quality Control . . . . . . . . . . . . . . . . . 13

3.4 Analysis Results . . . . . . . . . . . . . . . . . . 15

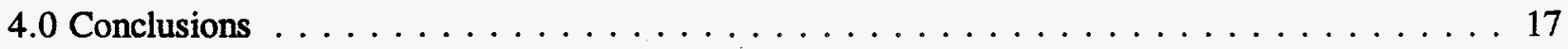

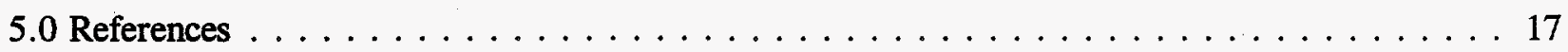

6.0 Further Reading $\ldots \ldots \ldots \ldots \ldots \ldots \ldots \ldots \ldots \ldots \ldots \ldots \ldots$

Distribution List $\ldots \ldots \ldots \ldots \ldots \ldots \ldots \ldots \ldots \ldots \ldots \ldots \ldots \ldots \ldots \ldots \ldots$ 


\section{Tables}

2.1 Analysis Procedures and Typical Detection Limits of Target Inorganic Analytes . . . . . 8

2.2 List of PNL Inorganic Samples, Controls, and Gravimetric Results Obtained From A Heated Tube Inserted into the Headspace of Tank C-101 on $9 / 1 / 94 \ldots \ldots$

2.3 Inorganic Vapor Sample Results Obtained From a Heated Tube Inserted into the Headspace of Tank $\mathrm{C}-101$ on $9 / 1 / 94 \ldots \ldots \ldots \ldots \ldots \ldots \ldots$

3.1 TO-14 Analysis for Samples from the Headspace of Tank C-101 in SUMMA ${ }^{\mathrm{m}}$ Canisters Collected on $9 / 1 / 94 \ldots \ldots \ldots$. . . . . . . . . . . . . . . 19

3.2 Tentatively Identified Compounds and Estimated Concentrations from the Headspace of Tank C-101 in SUMMA ${ }^{\text {Tx }}$ Canisters Collected on $9 / 1 / 94 \ldots \ldots \ldots$. . . . . . . . . 21

3.3 Tentatively Identified Compounds and Estimated Concentrations for Ambient Air Samples Collected Near Tank C-101 in SUMMA Canisters on 9/1/94 . . . . . . . . 25

\section{Figures}

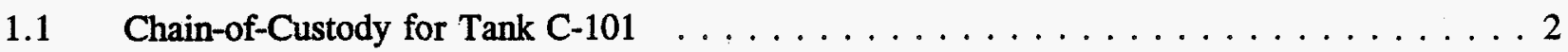

3.1 Total Ion Chromatogram for Hanford Waste Tank C-101 SUMMA ${ }^{\text {TM }}$ Canister Sample S4056-A05-033 Collected on 9/1/94 26 


\subsection{Introduction}

This report describes results of the analyses of tank-headspace samples taken from the Hanford waste Tank 241-C-101 (referred to as Tank C-101) and the ambient air collected $\sim 30 \mathrm{ft}$ upwind near the tank and through the VSS near the tank. Pacific Northwest Laboratory (PNL)(a) contracted with Westinghouse Hanford Company (WHC) to provide sampling devices and to analyze inorganic and organic analytes collected from the tank headspace and ambient air near the tank. The sample job was designated S4056, and samples were collected by WHC on September 1, 1994, using the vapor sampling system (VSS).

Sampling devices, including six sorbent trains (for inorganic analyses), and five SUMMA ${ }^{\mathrm{TM}}$ canisters (for organic analyses) were supplied to the WHC sampling staff on August 15, 1994. Samples were taken (by WHC) from the tank headspace on September 1 and were returned to PNL from the field on September 8. Inorganic (sorbent trap) samples were delivered to PNL on chain of custody (COC) 007502 (see Figure 1.1a). The SUMMA ${ }^{\mathrm{TM}}$ canisters were delivered on COC 007501 (see Figure 1.1b).

The samples were inspected upon delivery to the 326/23B laboratory and logged into PNL record book 55408 before implementation of PNL Technical Procedure PNL-TVP-07 ${ }^{(b)}$. Custody of the sorbent traps was transferred to PNL personnel performing the inorganic analysis and stored at refrigerated $\left(\leq 10^{\circ} \mathrm{C}\right)$ temperature until the time of analysis. The canisters were stored in the $326 / 23 \mathrm{~B}$ laboratory at ambient $\left(25^{\circ} \mathrm{C}\right)$ temperature until the time of the analysis. Access to the 326/23B laboratory is limited to PNL personnel working on the waste-tank safety program. Analyses described in this report were performed at PNL in the 300 area of the Hanford Reservation.

Analytical methods that were used are described in the text. In summary, sorbent traps for inorganic analyses containing sample materials were either weighed (for water analysis) or desorbed with the appropriate aqueous solutions (for $\mathrm{NH}_{3}, \mathrm{NO}_{2}$, and $\mathrm{NO}$ analyses). The aqueous extracts were analyzed either by selective electrode or by ion chromatography (IC). Organic analyses were performed using cryogenic preconcentration followed by gas chromatography/mass spectrometry (GC/MS).

(a) Pacific Northwest Laboratory is operated for the U. S. Department of Energy by Battelle Memorial Institute under Contract DE-AC06-76RLO 1830.

(b) PNL-TVP-07, Rev. 0, October 1994, Sample Shipping and Receiving Procedure for PNL Waste Tank Samples, PNLTechnical Procedure, Tank Vapor Project, Richland, Washington. 


\section{Westugnouse Hanford Company}

Custody Form Initiator

J. A. Edwards

R. A. Westberg

Company Contact

Project Designation/Sampling Locations 200 East Tank Farm 241-C-101 Tank

Ice Chest No. Vapor Sample SAF S4056

(VSS Truck)

Bill of Lading/Airbill No.

N/A

Method of Shipment

Government Truck

Shipped to

PNL
Telephone

Pager

373-0141

$85-3009$

Telephone

Collection Date

Preparation Date

Field Logbook No.

Offsite Property No. N/A

Sample Job
(509) $373-5734$

$\left.\sin _{00} 1 / 9-1-94\right) .9-1-94$

$08-15-94$

WHC-N- $-447-4$

Possible Sample Hazards/Remarks Unknown at time of sampling

Sample Identification

$$
\begin{aligned}
& \text { S4056 - A22 . 80W } \\
& \text { S4056 - A23 . 81W } \\
& \text { S4056 - A24 . 82W } \\
& \text { S4056 - A25.83W } \\
& \text { S4056 - A26. 84W } \\
& \text { S4056 - A27. 85W }
\end{aligned}
$$

$$
\begin{aligned}
& \text { S4056 - A28 . 86W } \\
& \text { S4056 - A29.87W } \\
& \text { S4056 - A30.88W }
\end{aligned}
$$

$\mathrm{NH}_{3} / \mathrm{NO}_{\mathrm{x}} / \mathrm{H}_{2} \mathrm{O}$ (Trap \# 1) Line \# 8

\begin{tabular}{|c|c|c|c|c|c|}
\hline I Field Transfer of Custody & & \multicolumn{2}{|c|}{ X] Chain of Possession } & \multicolumn{2}{|c|}{ (Sign and Print Names) } \\
\hline Relinquishted By & Date & Time & Received By & - Date & Time \\
\hline J. A. Edwards d Eluwarto & $08-15-94$ & 1015 & Andy Johnson $15 A$ & $08-15-94$ & $10^{\prime} 15$ \\
\hline Aat Marexts & 911794 & 1540 & S.M. Brown & $7 / 1 / 94$ & $+348-13$ \\
\hline 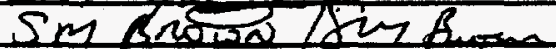 & & & AMIT SHARLSH & $29 / 8 / 94$ & 1330 \\
\hline & & & & & \\
\hline & & & & & \\
\hline Revised 02/28/94) & & & & & \\
\hline
\end{tabular}

$\mathrm{NH}_{3} / \mathrm{NO}_{x} / \mathrm{H}_{2} \mathrm{O}$ (Trap \# 2) Line \#10

$\mathrm{NH}_{3} / \mathrm{NO}_{x} / \mathrm{H}_{2} \mathrm{O}$ (Trap \# 3) Line \# 9

$\mathrm{NH}_{3} / \mathrm{NO}_{x} / \mathrm{H}_{2} \mathrm{O}$ (Trap \# 4) Line \#10

$\mathrm{NH}_{3} / \mathrm{NO}_{x} / \mathrm{H}_{2} \mathrm{O}$ (Trap \# 5) Line \# 8

$\mathrm{NH}_{3} / \mathrm{NO}_{x} / \mathrm{H}_{2} \mathrm{O}$ (Trap \# 6) Line \#10

$\mathrm{NH}_{3} / \mathrm{NO}_{2} / \mathrm{H}_{2} \mathrm{O}$ a-b-c (Trip Blank\# 1)

$\mathrm{NH}_{3} / \mathrm{NO}_{2} / \mathrm{H}_{2} \mathrm{O}$ a-b-c (Trip Blank\# 2)

$\mathrm{NH}_{3} / \mathrm{NO}_{2} / \mathrm{H}_{2} \mathrm{O}$ a-b-c (Trip Blank\# 3)

Disposal Method:

Disposed by:

Date/Time:

Figure 1.1a Chain of Custody for Inorganic Samples for Tank C-101 


\section{Westinghouse Hanford Company}

Custody Form Initiator

J. A. Edwards

Company Contact

R. A. Westberg

CHAIN OF CUSTODY

WHC 007501

Project Designation/Sampling Locations 200 East Tank Farm

241-C-101 Tank

Ice Chest No.

Vapor Sample SAF S4056

(VSS Truck)

Bill of Lading/Airbill No.

N/A

Method of Shipment

- Government Truck

Shipped to

PNL

Possible Sample Hazards/Remarks Unknown at time of sampling
Telephone

Pager

$(509) 373 \quad-0141$

$85-3009$

Telephone

Collection Date

Preparation Date

Field Logbook No. WHC-N-64Z--4 Offsite Property No. N/A

Sample Job
(509) 373-5734

8n: $5-1-94$ $08-1-24,9-1.94$ $08-\overline{1} \overline{5}-94$
S4056-A01 - 026 SAP Ref

S4056 - A02 - 031 SAP Ref

$\mathrm{S} 4056$ - A05 - 033

S4056 - A07 - 058

$S 4056-A 09-062$
SAP Ref

SAP Ref

SAP Ref
Ambient air SUMMA \#1, Upwind VSS (PNL)

Ambient air SUMMA \#2, Through VSS (PNL)

SUMMA \#4 (PNL)

SUMMA \#6 (PNL)

SUMMA \#8 (PNL)

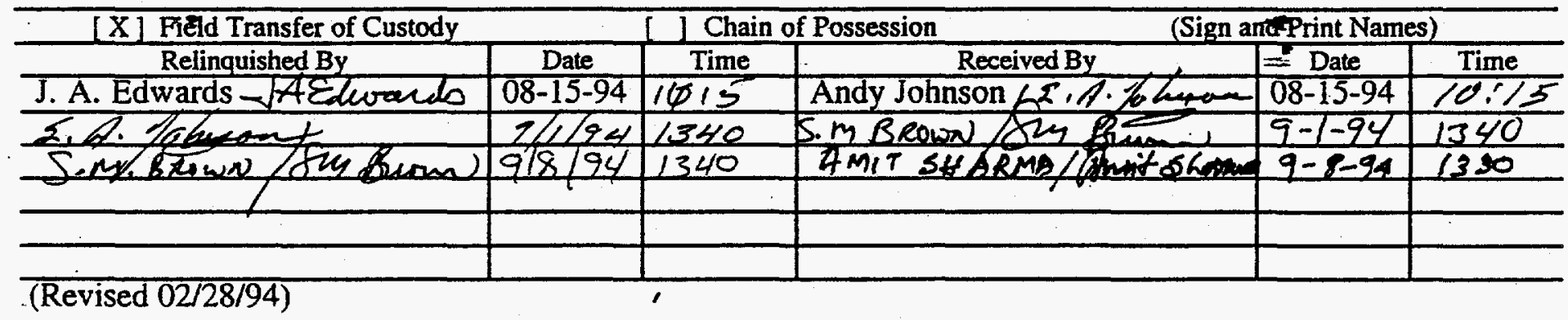

Final Sample Disposition

Disposal Method:

Disposed by:

Figure 1.1b Chain of Custody for Inorganic Samples for Tank C-101

Date/Time: 



\subsection{Inorganic}

Solid sorbent traps, prepared in multi-trap sampling trains, were supplied to WHC for sampling the headspace of Tank C-101 using the VSS. Blanks, spiked blanks (when requested), and exposed samples were returned to PNL for analysis. Analyses were performed to provide information on the tank-headspace concentration of the following analytes: ammonia $\left(\mathrm{NH}_{3}\right)$, nitrogen dioxide $\left(\mathrm{NO}_{2}\right)$, nitric oxide (NO), and water $\left(\mathrm{H}_{2} \mathrm{O}\right)$. Procedures were similar to those developed previously during sample jobs performed with the VSS connected to the headspace of Tank C-103 (Ligotke et al. 1994). During those sample jobs, control samples provided validation that samples were effectively trapping $\mathrm{NH}_{3}$ and mass. Analytical accuracy was estimated based on procedures used. Sample preparation and analyses were performed following PNL quality assurance (QA) impact level (IL) III requirements.

\subsection{Standard Sampling Methodology}

Standard glass tubes containing sorbent materials to trap vapors of selected analytes of $\mathrm{NH}_{3}$, $\mathrm{NO}_{2}$, NO, and $\mathrm{H}_{2} \mathrm{O}$ (SKC Inc., Eighty Four, Pennsylvania) were obtained, prepared, and submitted for use by WHC. The sorbent traps were selected based on their use by the Occupational Safety and Health Administration (OSHA) to perform workplace monitoring, and because of available procedures and verification results associated with that particular application. The typical sorbent traps used consisted of a glass tube containing a sorbent material specific to the compound of interest. In general, the tubes contained two sorbent layers, or sections: the first layer was the primary trap, and the second layer provided an indication of breakthrough. In the tubes, sorbent layers are generally held in packed layers separated by glass wool. The sorbent traps, having glass-sealed ends, were received from the vendor.

The type and nominal quantity of sorbent material varied by application. Sorbent traps selected for the tank sample job included the following products. The $\mathrm{NH}_{3}$ sorbent traps contained carbon beads impregnated with sulfuric acid; nominally, $500 \mathrm{mg}$ were contained in the primary and $250 \mathrm{mg}$ in the breakthrough sections. The $\mathrm{NH}_{3}$ was chemisorbed as ammonium sulfate $\left\{\left(\mathrm{NH}_{4}\right)_{2} \mathrm{SO}_{4}\right\}$. The $\mathrm{NO}_{2}$ traps contained a zeolite impregnated with triethanolamine (TEA), with $400 \mathrm{mg}$ in the primary and $200 \mathrm{mg}$ in the breakthrough sections. The $\mathrm{NO}_{2}$ was absorbed and disproportionated to equi-molar quantities of nitrite ions $\left(\mathrm{NO}_{2}{ }^{-}\right)$and nitrate ions $\left(\mathrm{NO}_{3}{ }^{-}\right)$. Glass tubes containing $800 \mathrm{mg}$ of an oxidant such as chromate were used to convert $\mathrm{NO}$ to $\mathrm{NO}_{2}$. The converted $\mathrm{NO}$ was then collected as nitrite and nitrate in an $\mathrm{NO}_{2}$ trap. The water traps contained $300 \mathrm{mg}$ of silica gel in the primary and $150 \mathrm{mg}$ in the breakthrough sorbent sections.

Samples provided by PNL to trap inorganic compounds include all or some of the following: samples, spiked samples, spares, single-trap blanks, and spiked blanks. The samples of each type were prepared from same-lot batches, with the oxidizer sections of the $\mathrm{NO}_{\mathrm{x}}$ sorbent trains having been stored previously in a freezer. After sample preparation, all samples, spiked samples, blanks, and spiked blanks were stored in a freezer, primarily because of handling recommendations for the oxidizer tubes attached to some samples. After receipt of exposed and radiologically cleared samples from WHC and disassembly of the sorbent trains, samples were provided to the analytical laboratory at ambient temperature, and selected oxidizer sections were returned to a freezer until completion of analysis. 
The sorbent traps were prepared in multi-trap sorbent trains configured so sample flow passed in order through the traps, targeting specific analytes, and then through a desiccant trap. The specific order of traps within the various sorbent trains is described in Section 2.4. The ends of the glass-tube traps were broken, and the traps were weighed and then connected to each other using uniform lengths of 3/8-in. perfluoroalkoxy (PFA)-grade Teflon tubing. The tubing was heated in hot air and forced over the open ends of the traps to form a tight seal. The inlets of the sorbent trains each consisted of a short section of tubing having a 3/8-in. stainless steel Swagelok nut, sealed using a Swagelok ${ }^{\circledR}$ cap. The trailing ends of the sorbent trains (the downstream end of the traps containing silica gel) were each sealed with red-plastic end caps provided by the manufacturer. The sorbent-trap trains remained sealed other than during the actual sampling periods. C-Flex ${ }^{\circledR}$ tubing was provided by WHC to connect the downstream ends of the sorbent trains to the sampling exhaust-manifold connections.

2.1.1 Concentration Calculations. The concentrations of target compounds in the tank headspace were determined from sample results, assuming effective sample transport to the sorbent traps. Concentration, in parts per million by volume (ppmv), was determined by dividing the mass of the compound, in $\mu \mathrm{mol}$, by the volume of the dried tank air sampled in mol. The micromolar sample mass was determined by dividing the compound mass, in $\mu \mathrm{g}$, by the molecular weight of the compound, in $\mathrm{g} / \mathrm{mol}$. The molar sample volume was determined, excluding water vapor, by dividing the standard sample volume (at $0^{\circ} \mathrm{C}$ and 760 torr), in $\mathrm{L}$, by $22.4 \mathrm{~L} / \mathrm{mol}$. For example, the concentration $\left(\mathrm{C}_{\mathrm{v}}\right)$ of a 3.00-L sample containing $75.0 \mu \mathrm{g}$ of $\mathrm{NH}_{3}$ equals

$$
\mathrm{C}_{\mathrm{v}}=\frac{75.0 \mu \mathrm{g}}{17 \mathrm{~g} / \mathrm{mol}}\left(\frac{3.00 \mathrm{~L}}{22.4 \mathrm{~L} / \mathrm{mol}}\right)^{-1}=32.9 \mathrm{ppmv}
$$

This calculational method produces concentration results that are slightly conservative (greater than actual) because the volume of water vapor in the sample stream is neglected. The volume of water vapor is not included in the measured sampled volume because of its removal in desiccant traps upstream of the mass flowmeters. However, the bias is generally expected to be small. For a tankheadspace temperature of $35^{\circ} \mathrm{C}$, the magnitude of the bias would be about 1 to $6 \%$, assuming tankheadspace relative humidities of 20 to $100 \%$, respectively. The concentration of mass (determined gravimetrically) was also per dry-gas volume at standard conditions.

\subsection{Analytical Procedures}

The compounds of interest were trapped using solid sorbents and chemisorption (adsorption of water vapor). Analytical results were based on extraction and analysis of selected ions. Analytical procedures used are specified herein and compiled in PNL-MA-599.

2.2.1 Ammonia Analysis. The sorbent material from the $\mathrm{NH}_{3}$-selective sorbent traps was placed into labeled $20-\mathrm{mL}$ glass scintillation vials. Vials containing front-, or primary-, section sorbent: material were treated with $10.0 \mathrm{~mL}$ of deionized water (DIW), and vials containing back-up-section sorbent material were treated with $5.0 \mathrm{~mL}$ of DIW. After extraction, the $\mathrm{NH}_{3}$ sorbent traps were analyzed using the selective ion electrode (SIE) procedure PNL-ALO-226 Ammonia (Nitrogen) in Aqueous Samples $\}$. Briefly, this method includes 1) preparing a $1000-\mu \mathrm{g} / \mathrm{mL}$ (ppm) $\mathrm{NH}_{3}$ stock standard solution from dried reagent-grade $\mathrm{NH}_{4} \mathrm{Cl}$ and DIW on the day analyses are performed; 2) preparing $0.1-, 0.5-, 1.0-, 10-$, and $100-\mathrm{ppm} \mathrm{NH}_{3}$ working calibration standards by serial dilution of the freshly made stock standard; 3 ) generating an initial calibration curve from the measured 
electromotive force (emf) signal versus $\mathrm{NH}_{2}$ concentration data obtained for the set of working standards; 4) performing a calibration-verification check, using one of the midrange standards, after analyzing every four or five samples; 5 ) continuing this sequence until all samples of the batch have been measured, including duplicates and spiked samples; and 6) remeasuring the complete set of calibration standards (at the end of the session). Emf signal measurements obtained for samples are compared to those for standards, either graphically or algebraically (using linear regression), to determine $\mathrm{NH}_{3}$ concentration in the samples.

2.2.2 Nitrite Analysis. The sorbent traps for $\mathrm{NO}_{2}$ and $\mathrm{NO}$ were desorbed in an aqueous TEA and n-butanol solution and analyzed by suppressed-conductivity ion chromatography (SCIC) for nitrite according to PNL-ALO-212, Rev. 1 (Determination of Inorganic Anions by Ion Chromatography) modified to obviate interferences by concentrations of non-target analytes. Specifically, the modifications used were 1) eluent $1.44 \mathrm{mM} \mathrm{Na}_{2} \mathrm{CO}_{3}+1.8 \mathrm{mM} \mathrm{NaHCO}$ at $2.0 \mathrm{~mL} / \mathrm{min}$, 2) one guard column (AG4A) and two separator columns (AS4A) in series instead of just one separator column, and 3) all standards, samples, and blanks injected into the IC sample loop through $0.45-\mu \mathrm{m}$ syringe filters.

For the analysis, the sorbent materials were placed into labeled $20-\mathrm{mL}$ glass scintillation vials. To each vial, $3.0 \mathrm{~mL}$ of desorbing solution (15 $\mathrm{g}$ TEA $+1 \mathrm{~mL}$ n-butanol in $1.0 \mathrm{~L} \mathrm{DIW}$ ) was added. Primary sorbent-tube sample materials and back-up (breakthrough) sorbent-trap materials were analyzed separately using identical procedures. Each analytical session was conducted as follows. Working nitrite standards $(0,0.1,0.25$, and $0.5 \mathrm{ppm})$ were prepared by diluting a stock nitrite standard with desorbing solution. An initial calibration curve was prepared from the instrument response (chromatographic peak height) versus nitrite standard concentration data for the set of working standards. A calibration verification check using one of the midrange standards was performed after the analysis of every six samples. If the instrument response indicated that sample nitrite concentration was outside the calibration range ( $>0.5 \mathrm{ppm}$ nitrite), the sample was diluted with desorbing solution and reanalyzed. After all samples of a batch were analyzed, the complete set of calibration standards was remeasured to verify consistent instrument response, and the analytical session was terminated.

Instrument responses (peak height) observed for samples were compared to those for standards to determine the nitrite concentration of the samples. Because $\mathrm{NO}_{2}$ and $\mathrm{NO}$ converted to $\mathrm{NO}_{2}$ were collected on the sorbent as equal quantities of nitrite and nitrate, and the analysis was specific for nitrite, the molar masses of $\mathrm{NO}_{2}$ and $\mathrm{NO}$ were determined by doubling the analytically determined molar mass of nitrite.

2.2.3 Mass (Water) Analysis. Sorbent traps used to make each sample train were weighed using a semi-micro mass balance after labeling and breaking the glass tube ends, without plastic end caps. After receipt of exposed samples, the sorbent traps were again weighed to determine the change in mass. Records of the measurements were documented on sample-preparation data sheets. The mass concentration, generally roughly equal to the concentration of water, was determined by dividing the combined change in mass from all traps in a sorbent train by the actual volume of gas sampled. Blanks and spiked blanks were included to provide information on uncertainty. 


\subsection{Quality Assurance/Quality Control}

Analytical-work was performed according to quality levels identified in the project QA plan and several PNL documents. The samples were analyzed following PNL QA IL III. The PNL documents include PNL-MA-70 (Part 2), PNL-MA-599, PNL-ALO-212, PNL-ALO-226, PNL-ALO271 , and MCS-033. A summary of the analysis procedures and limits for the target inorganic compounds is provided in Table 2.1. From the table, it can be seen that the minimum detection limit (MDL) required to resolve the analyte at one-tenth of the recommended exposure limit (REL) for each of the target analytes is achieved using current procedures and with a vapor-sample volume of $3 \mathrm{~L}$ and a desorption-solution volume of $3 \mathrm{~mL}\left(10 \mathrm{~mL}\right.$ for $\left.\mathrm{NH}_{3}\right)$.

Table 2.1 Analysis Procedures and Detection Limits of Target Inorganic Analytes

\begin{tabular}{|c|c|c|c|c|c|}
\hline Analyte & Formula & Procedure & $\begin{array}{c}\text { REL }^{(a)} \\
\text { (ppmv) }\end{array}$ & $\begin{array}{l}0.1 \times \mathrm{REL}^{(\mathrm{a})} \\
(\mathrm{ppmv}) \\
\end{array}$ & $\begin{array}{l}\mathrm{MDL}^{(b)} \\
\text { (ppmv) }\end{array}$ \\
\hline Ammonia & $\mathrm{NH}_{3}$ & PNL-ALO-226 & 25 & 2.5 & 0.5 \\
\hline Nitrogen Dioxide & $\mathrm{NO}_{2}$ & PNL-ALO-212 & 1 & 0.1 & 0.02 \\
\hline Nitric oxide & NO & PNL-ALO-212 & 25 & 2.5 & 0.02 \\
\hline Mass (water) ${ }^{(\mathfrak{c})}$ & $\mathbf{n} / \mathbf{a}$ & $\mathrm{n} / \mathrm{a}$ & $\mathbf{n} / \mathbf{a}$ & $\mathrm{n} / \mathrm{a}$ & $\mathrm{n} / \mathrm{a}$ \\
\hline
\end{tabular}

(a) Target analytical limits are equal to one tenth of the REL.

(b) MDL is defined as the vapor concentration that can be detected with an uncertainty equal to about the magnitude of the measurement. The uncertainty is expected to reduce to about one quarter of the magnitude of the measurement at a concentration of four times the MDL. The MDLs were based on the assumption that $3 \mathrm{~L}$ of vapor are sampled; if greater volumes of vapor are sampled, correspondingly smaller MDLs can be achieved. The MDLs were also based on desorbing-solution volumes of $10 \mathrm{~mL}$ for $\mathrm{NH}_{3}$ and $3 \mathrm{~mL}$ for the other analytes.

(c) The vapor-mass concentration, thought to be largely water vapor, is determined for estimates of humidity.

The accuracy of concentration measurements depends on errors associated with both sampling and analysis (see Section 2.4). Sampling information, including sample volumes, was provided by WHC; sample volume uncertainty was not provided. The accuracy of analytical results depends on the method used. For $\mathrm{NH}_{3}$ analyses, the accuracy of laboratory measurements by SIE was estimated to be $\pm 5 \%$ relative, independent of concentration at $1 \mu \mathrm{g} / \mathrm{mL}$ or greater levels. The uncertainty includes preparation of standards, purity of the ammonium salt used to prepare standards, potential operator bias, ambient temperature variations, etc. Unfortunately, no known National Institute for Standards and Technology (NIST)-traceable standard reference material (SRM) is available against which to compare working standards. Similarly, no known NIST SRM is available for nitrite analysis (for $\mathrm{NO}_{2}$ and NO). Based on experience in comparing nitrite working standards prepared from several different sources and factors mentioned for $\mathrm{NH}_{3}$ above, the estimated maximum bias for samples derived from sampling for $\mathrm{NO}_{2}$ is $\pm 10 \%$, and for samples derived from sampling for NO, it is $\pm 5 \%$ relative. The accuracy of measurements of sample mass is $\pm 0.05 \mathrm{mg}$, or much less than $1 \%$ of the mass changes of most samples, and roughly $5 \%$ or less of the mass change of most blanks. 


\subsection{Inorganic Sample Results}

Samples were obtained by WHC from the headspace of Tank C-101 on 9/1/94 using the VSS. The sample job designation number was \$4056. Samples were prepared, submitted to WHC, and then returned and analyzed to provide information on the concentrations of $\mathrm{NH}_{3}, \mathrm{NO}_{2}, \mathrm{NO}$, and $\mathrm{H}_{2} \mathrm{O}$. Sampling and analysis for $\mathrm{SO}_{\mathrm{x}}$ and $\mathrm{HCN}$ were not requested. The inorganic samples were received from WHC on $9 / 8 / 94$; the sample-volume information was received on $9 / 12 / 94$.

A list of samples, sampling information, sample volumes, and gravimetric results is shown in Table 2.2. The types of sample trains used and the order of sorbent traps within each train are also shown in the table. For example, the sorbent train $\mathrm{NH}_{3} / \mathrm{NO}_{\mathrm{x}} / \mathrm{H}_{2} \mathrm{O}$ contained an $\mathrm{NH}_{3}$ trap at the inlet end, an $\mathrm{NO}_{\mathrm{x}}$ series in the middle (Section 2.4.2), and a desiccant trap at the outlet end. Analytical mass and concentration results are shown in Table 2.3. Sample volumes were provided by WHC; sample-volume uncertainty was not provided. Tank-headspace concentration results (Table 2.3) are based on this information, and the listed uncertainties equal plus-or-minus one standard deviation of the individual results from each set of samples. Where analytical results from each set of samples were nearly indistinguishable from those of blanks, indicating very low vapor concentrations of the analyte, the concentration results (Table 2.3) are listed as "less than or equal to" a probable maximum value determined by subtracting the average of the blanks less one standard deviation from the average of the samples plus one standard deviation. Results of control samples, such as spiked blanks, are discussed in this section. Spiked blanks, when used, were transported to the field but not opened. Spiked samples, when used, were opened in the field and used to collect tank vapors. Sample results were not corrected for the percentage recoveries of spiked blanks.

2.4.1 Ammonia Results. The concentration of $\mathrm{NH}_{3}$ was $98 \pm 1 \mathrm{ppmv}$, based on all six samples. The $\mathrm{NH}_{3}$ quantities found in the sorbent traps ranged from 12.9 to $13.3 \mu \mathrm{mol}$ in the front sorbent sections with no indication of breakthrough. Blank corrections, $\leq 0.06 \mu \mathrm{mol}$ in front and $\leq 0.03$ $\mu \mathrm{mol}$ in back sorbent sections, were less than $1 \%$ of collected quantities and were neglected.

Although spiked blanks were not tested, the percentage recoveries of three sets of blanks spiked with 12.2, 22.3, and $46.4 \mu \mathrm{mol} \mathrm{NH}_{3}$ were $101 \pm 4 \%, 109 \pm 2 \%$, and $104 \pm 1 \%$, respectively, during related sample jobs (Clauss et al. 1994; Ligotke et al. 1994). The analysis of one sample was duplicated and yielded repeatabilities of $\pm 4 \%$. One sample leachate was spiked after initial analysis with roughly the quantity of $\mathrm{NH}_{3}$ in the sample and yielded a percentage recovery of $97 \%$. A 5-point calibration was performed over an $\mathrm{NH}_{3}$ range of 0.1 to $1000 \mu \mathrm{g} / \mathrm{mL}$.

2.4.2 Nitrogen Oxides Results. Measurements of $\mathrm{NO}_{2}$ and $\mathrm{NO}$ were made using six 5-segment $\mathrm{NH}_{3} / \mathrm{NO}_{\mathrm{x}} / \mathrm{H}_{2} \mathrm{O}$ sorbent-trap trains (the $\mathrm{NO}_{\mathrm{x}}$ trains consisted of $\mathrm{NO}_{2}$ trap, oxidizer, and $\mathrm{NO}_{2}$ trap). Related sample jobs, performed using the VSS in Tanks BY-104, -105 , and -106 both with and without $\mathrm{NO}_{x}$ trains protected by a leading $\mathrm{NH}_{3}$ trap (e.g., Clauss et al. 1994), indicated that the presence of the upstream $\mathrm{NH}_{3}$ traps resulted in NO concentrations that were about 1.3- to 1.6-fold less than those from unprotected $\mathrm{NO}_{2}$ traps. The $\mathrm{NO}_{2}$ concentrations were also potentially less following an $\mathrm{NH}_{3}$ trap.

The concentrations of $\mathrm{NO}_{2}$ and $\mathrm{NO}$ were $\leq 0.04$ and $1.5 \pm 0.1 \mathrm{ppmv}$, respectively. Blankcorrected $\mathrm{NO}_{2}^{-}$quantities in the sorbent traps averaged $\leq 0.0027 \mu \mathrm{mol}\left(\mathrm{NO}_{2}\right.$ samples) and $0.099 \mu \mathrm{mol}$ (NO samples). Nitrite blank levels used to correct data were $0.0142 \pm 0.0016 \mu \mathrm{mol}$ in front and $0.0071 \pm 0.0004 \mu \mathrm{mol}$ in back sorbent sections and were based on blanks from this sample job and those from the related sample job for Tank C-102. The blanks from the two sample jobs were pooled because analyses were only performed on selected blanks. Although spiked blanks were not tested, 
Table 2.2 Inorganic Samples, Controls, and Gravimetric Results Obtained From a Heated Tube Inserted into the Headspace of Tank C-101 on 9/1/94

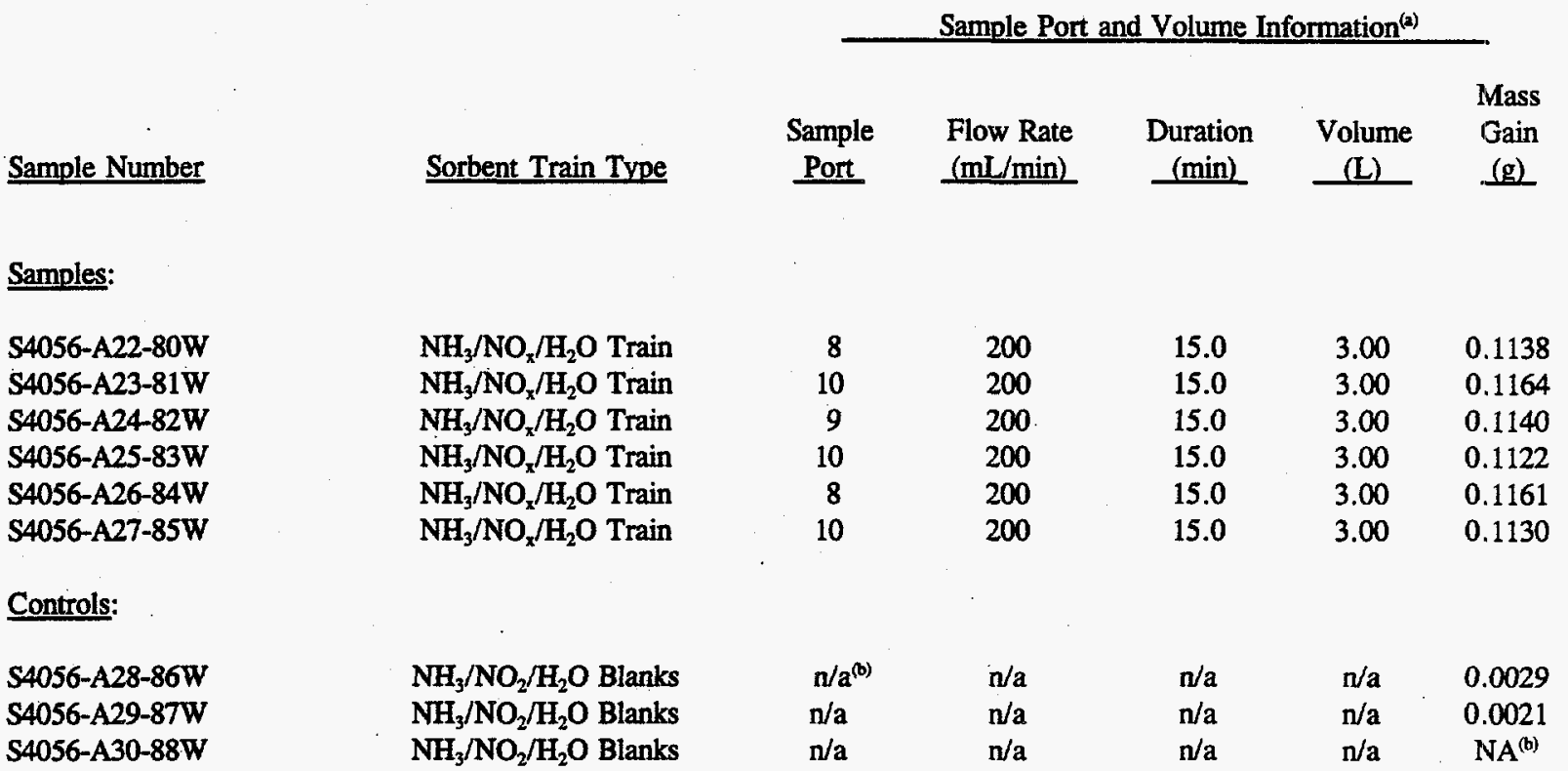

(a) Sampling information and dry-gas sample volumes, corrected to $0^{\circ} \mathrm{C}$ and 760 torr, were provided by WHC. Uncertainty values were not provided with sample-volume results.

(b) $\mathrm{n} / \mathrm{a}=$ not applicable. $\mathrm{NA}=$ not analyzed.

blanks spiked with $0.0064,0.047,0.11$, and $0.74 \mu \mathrm{mol} \mathrm{NO}_{2}^{-}$during related sample jobs yielded percentage recoveries of $153 \pm 14 \%, 103 \pm 4 \%, 106 \pm 8 \%$, and $111 \pm 7 \%$, respectively (Clauss et al. 1994; Ligotke et al.). No samples were reanalyzed to check repeatability. No sample leachates were spiked after initial analysis with quantities of $\mathrm{NO}_{2}^{-}$to test analytical percentage recoveries. A 4point calibration was performed over a concentration range of 0 to $0.5 \mu \mathrm{g} \mathrm{NO}_{2}^{-}$per $\mathrm{mL}$ in the desorbing matrix.

2.4.3 Gravimetric Results. The mass concentration of material collected in the sorbent-trap trains, believed to be primarily water vapor, was $36 \pm 1 \mathrm{mg} / \mathrm{L}$. The result was based on an average mass gain of $109 \mathrm{mg}$ from all six $\mathrm{NH}_{3} / \mathrm{NO}_{2} / \mathrm{H}_{2} \mathrm{O}$ sample trains. The blank correction applied to the results was $5 \pm 2 \mathrm{mg}$ per sample train, based on an average per-trap mass loss of $1.0 \pm 0.4 \mathrm{mg}$ from eight of nine blank traps. Three traps each of $\mathrm{NH}_{3}, \mathrm{NO}_{2}$, and $\mathrm{H}_{2} \mathrm{O}$ were prepared and analyzed as trip blanks. Although no spiked blanks were tested, the percentage recovery of mass from three blank $\mathrm{H}_{2} \mathrm{O}$ traps spiked with $51 \mathrm{mg}$ water was $103 \pm 2 \%$ during a related sample job (Clauss et al. 1994). 
Table 2.3 Inorganic Vapor Sample Results Obtained From a Heated Tube Inserted into the Headspace of Tank C-101 on 9/1/94

Analytical Results ( $\mu \mathrm{mol})$

\begin{tabular}{|c|c|c|c|c|}
\hline \multicolumn{3}{|c|}{ Analytical Results ( $\mu \mathrm{mol})$} & \multirow[b]{2}{*}{$\begin{array}{c}\text { Sample } \\
\text { Volume } \\
\text { (L) } \\
\end{array}$} & \multirow[b]{2}{*}{$\begin{array}{c}\text { Vapor }_{(\mathrm{a})} \\
\text { Concentration } \\
\text { (ppmv) } \\
\end{array}$} \\
\hline $\begin{array}{l}\text { Front } \\
\text { Section } \\
\end{array}$ & $\begin{array}{c}\text { Back } \\
\text { Section }\end{array}$ & $\begin{array}{c}\text { Total }^{(\mathrm{b})} \\
\text { Blank-Corrected }\end{array}$ & & \\
\hline & & $13.2^{(\mathrm{c})}$ & ${\underline{3.00^{(c)}}}^{(1)}$ & $\underline{98 \pm 1^{(c)}}$ \\
\hline 13.3 & $\leq 0.03$ & 13.3 & 3.00 & 99 \\
\hline 12.9 & $\mathbf{N A}^{(d)}$ & 12.9 & 3.00 & 96 \\
\hline 13.2 & NA & 13.2 & 3.00 & 99 \\
\hline 13.2 & NA & 13.2 & 3.00 & 99 \\
\hline 13.3 & NA & 13.3 & 3.00 & 99 \\
\hline \multirow[t]{2}{*}{13.2} & NA & 13.2 & 3.00 & 99 \\
\hline & & $\leqq 0.0029$ & $\underline{3.00}$ & $\leq 0.04$ \\
\hline 0.0142 & 0.0078 & $n / a^{(d)}$ & 3.00 & $\mathrm{n} / \mathrm{a}$ \\
\hline 0.0128 & NA & $\mathrm{n} / \mathrm{a}$ & 3.00 & $\mathrm{n} / \mathrm{a}$ \\
\hline 0.0128 & NA & $\mathrm{n} / \mathrm{a}$ & 3.00 & $n / a$ \\
\hline 0.0130 & 0.0066 & $\mathbf{n} / \mathbf{a}$ & 3.00 & $\mathrm{n} / \mathbf{a}$ \\
\hline 0.0141 & NA & $\mathrm{n} / \mathbf{a}$ & 3.00 & $\mathbf{n} / \mathbf{a}$ \\
\hline \multirow[t]{2}{*}{0.0133} & NA & $\mathrm{n} / \mathrm{a}$ & 3.00 & $n / a$ \\
\hline & & $\underline{0.099}$ & $\underline{3.00}$ & $\underline{1.5 \pm 0.1}$ \\
\hline 0.111 & 0.0081 & 0.097 & 3.00 & 1.4 \\
\hline 0.108 & NA & 0.094 & 3.00 & 1.4 \\
\hline 0.104 & NA & 0.090 & 3.00 & 1.3 \\
\hline 0.121 & 0.0080 & 0.107 & 3.00 & 1.6 \\
\hline 0.121 & $\mathrm{NA}$ & 0.107 & 3.00 & 1.6 \\
\hline \multirow[t]{2}{*}{0.114} & NA & 0.100 & 3.00 & 1.5 \\
\hline & & $109 \mathrm{mg}$ & $\underline{3.00}$ & $\underline{36} \pm 1 \mathrm{mg} / \mathrm{L}$ \\
\hline $\mathrm{n} / \mathrm{a}$ & $\mathrm{n} / \mathrm{a}$ & 109 & 3.00 & 36 \\
\hline $\mathrm{n} / \mathrm{a}$ & $\mathrm{n} / \mathrm{a}$ & 111 & 3.00 & 37 \\
\hline $\mathrm{n} / \mathrm{a}$ & $\mathrm{n} / \mathrm{a}$ & 109 & 3.00 & 36 \\
\hline $\mathbf{n} / \mathbf{a}$ & $\mathrm{n} / \mathrm{a}$ & 107 & 3.00 & 36 \\
\hline$n / a$ & $\mathrm{n} / \mathrm{a}$ & 111 & 3.00 & 37 \\
\hline $\mathrm{n} / \mathrm{a}$ & $\mathrm{n} / \mathrm{a}$ & 108 & 3.00 & 36 \\
\hline
\end{tabular}

\section{Sample \\ $\mathrm{NH}_{3}$ Samples:}

S4056-A22-80W

S4056-A23-81W

S4056-A24-82W

S4056-A25-83W

S4056-A26-84W

S4056-A27-85W

$\mathrm{NO}_{2}$ Samples:

S4056-A22-80W

S4056-A23-81W

S4056-A24-82W

S4056-A25-83W

S4056-A26-84W

S4056-A27-85W

NO Samples:

S4056-A22-80W

S4056-A23-81W

S4056-A24-82W

S4056-A25-83W

S4056-A26-84W

S4056-A27-85W

Gravimetric Samples (mg.mg/L):

S4056-A22-80W

S4056-A23-81W

S4056-A24-82W

S4056-A25-83W

S4056-A26-84W

S4056-A27-85W

(a) Blank-corrected vapor concentrations were calculated using WHC-reported dry-air sample volumes (corrected to $0^{\circ} \mathrm{C}$ and 760 torr). In the calculation for concentration, the nitrite values (listed) were doubled to account for unanalyzed nitrate. Sample results were not corrected for percentage recovery of spiked samples or spiked blanks.

(b) Total blank-corrected analyte masses (nitrite for $\mathrm{NO}_{2}$ and $\mathrm{NO}$ ) were determined, when significant, by subtracting the quantity of analyte found in blanks from that found in samples. The levels of analytes found in blanks are described in the subsections of Section 2.4 .

(c) Underlined values represent the average of the set of samples. Concentrations uncertainty equals \pm 1 standard deviation (absolute) for each set of samples. The use of " $\leq$ " is defined in Section 2.4.

(d) NA = not analyzed; $\mathrm{n} / \mathrm{a}=$ not applicable. Only selected back sorbent sections were analyzed. 



\subsection{Organic}

\subsection{SUMMA ${ }^{\text {TM }}$ Canister Preparation}

Before sending SUMMA ${ }^{\mathrm{TM}}$ canisters out to the field for sampling, the canisters are cleaned and verified contaminant free according to PNL Technical Procedure PNL-TVP-02 ${ }^{(a)}$. The cleaning procedure uses an EnTech 3000 cleaning system that controls 1) filling the canisters with purified humid air and 2) evacuating, for several cycles with applied heat, before allowing the canister to evacuate overnight. The canister is filled a final time with purified humid air for analysis by PNL Technical Procedure PNL-TVP-01 ${ }^{(b)}$, which is a modification of U.S. Environmental Protection Agency (EPA) compendium Method TO-14. If the canister is verified clean, free of TO-14 contaminants to a level of five parts per billion by volume (ppbv), the canister is evacuated in 30 in. $\mathrm{Hg}$, tagged, and stored for use in the field. Before sending the canisters out to the field for sampling, the canisters are prehumidified with $100 \mu \mathrm{L}$ of distilled water and labeled with a field-sampling identification. Canisters stored more than 30 but less than 60 days are re-evacuated and rehumidified before use. If stored more than 60 days, the canisters are recleaned and validated before use.

\subsection{Sample Analysis Method}

The SUMMA ${ }^{\mathrm{TM}}$ canister samples were analyzed according to PNL Technical Procedure PNL-TVP-03, Determination of TO-14 Volatile Organic Compounds in Hanford Waste Tank Headspace Samples Using SUMMA ${ }^{\mathrm{TM}}$ Passivated Canister Sampling and Gas Chromatographic-Mass Spectrometry Analysis, which is a modified version of EPA compendium Method TO-14. The method uses an EnTech cryoconcentration system interfaced with a Hewlett Packard (HP) 5971 GC/MS. The EnTech concentrator is used to pull a metered volume of sample air from the SUMMA ${ }^{\mathrm{TM}}$ canister, cryogenically concentrate the air volume, then transfer the volume to the GC/MS for analysis. A $100-\mathrm{mL}$ volume of sample is measured and analyzed from the tank headspace. The organic components in the sampled air are separated on an analytical column, J\&W Scientific DB-1 phase, $60-\mathrm{m}$ by $0.32-\mathrm{mm}$ internal diameter with $3-\mu \mathrm{m}$ film thickness. The GC oven is programmed to run a temperature gradient beginning at $40^{\circ} \mathrm{C}$, holding for $5 \mathrm{~min}$, and ramping at $4^{\circ} \mathrm{C}$ per min to a final temperature of $260^{\circ} \mathrm{C}$, with a 5-min hold.

\subsection{Quality Assurance/Quality Control}

Before the SUMMA ${ }^{\mathrm{TM}}$ tank samples were analyzed, a diagnostic check was performed on the GC/MS instrument by running an instrument "quick tune," as described in PNL-TVP-03. Upon satisfactory completion of the instrument diagnostic check, a blank volume of purified nitrogen was analyzed to check the cleanliness of the system. The instrument was then calibrated over six data points ranging from $2 \mathrm{ppbv}$ to $100 \mathrm{ppbv}$, using a standard gas mixture containing 40 volatile organic compounds listed in EPA compendium Method TO-14. A gas mixture containing

(a) Pacific Northwest Laboratory, 8/94. Cleaning SUMMA ${ }^{\mathrm{N}}$ Canisters and the Validation of the Cleaning Process, PNL-TVP-02 (Rev. 0), PNL Technical Procedure, Richland, Washington.

(b) Pacific Northwest Laboratory, 8/94. Determination of TO-14 Volatile Organic Compounds in Ambient Air using SUMMA ${ }^{\mathrm{Tm}}$ Passivated Canister Sampling and Gas Chromatographic-Mass Spectrometric Analysis, PNL-TVP-01 (Rev. 0). PNL Technical Procedure, Richland, Washington. 
bromochloromethane, 1,4-difluorobenzene, and chlorobenzene- $\mathrm{d}_{5}$ was used as an internal standard (IS) for all blank, calibration standard, and sample analyses. Analyte responses from sample components, ISs, and standards were obtained from the extracted ion plot from their selected mass ion. The calibration curve was generated by calculating the relative response ratios of the IS to . calibration-standard responses and plotting the ratios against the ratio of the calibration-standard concentration (in ppbv) to the IS concentration. A least-squares linear-regression routine was applied to the data set to generate the best-fit line for each compound. The equation for that line was then used to quantify the TO-14 compounds found in the tank samples.

3.3.1 Quantitation of TO-14 Results. The quantitative-analysis results for the TO-14 volatile organic compounds were calculated directly from the calibration curve generated using the IS method described above and in PNL-TVP-03. The conversion from $\mathrm{ppbv}$ to $\mathrm{mg} / \mathrm{m}^{3}$ assumes standard temperature and pressure (STP) conditions of 760 torr and $273 \mathrm{~K}$ and was calculated directly from the following equation:

$$
\mathrm{mg} / \mathrm{m}^{3}=\frac{(\mathrm{ppbv} / 1000) \times \mathrm{g} \mathrm{mol} \mathrm{wt} \text { of compound }}{22.4 \mathrm{~L} / \mathrm{mol}}
$$

3.3.2 Identification and Quantitation of Tentatively Identified Compounds. The tentatively identified compounds (TICs) are determined by mass-spectral interpretation and comparison of the spectra with the EPA/NIST/WILEY Library, which is a part of the HP 5971 instrument operating system. Chromatographic peaks with an area count greater than, or equal to, one half of the total area count of the chlorobenzene- $\mathrm{d}_{5}$ IS peak at the 20 -ppbv calibration level are tentatively identified and quantitatively estimated. This standard was chosen to determine the integration cutoff as it is in the middle of the chromatographic range and not in a region typically affected by coelution of other compounds. The quality of the mass-spectral searches was then reviewed by the principal investigators before the identification was assigned to each chromatographic peak.

The concentration of each TIC was estimated using a relative response factor calculated using a corrected total peak area for the IS chlorobenzene- $d_{s}$. Specifically, the total integrated area for the chlorobenzene- $d_{5}$ peak had to be corrected for possible coeluting compounds before calculating the response factor. The corrected total peak area for the IS was calculated by multiplying the IS quantitation ion by a correction factor based on the ratio of the total integrated peak area to the quantitation ion as measured in blank runs. The corrected peak area was then used to calculate a response factor using the IS concentration in $\mathrm{mg} / \mathrm{m}^{3}$ :

$$
\text { Response Factor }=\frac{I S \text { conc. }\left(\mathrm{mg} / \mathrm{m}^{3}\right)}{\text { IS peak area }}
$$

The calculated response factor was then multiplied by the TIC peak area to give an estimated concentration for that compound. For butane, the total peak area was multiplied by the response factor for chlorobenzene- $d_{5}$ to give an estimated concentration of $0.67 \mathrm{mg} / \mathrm{m}^{3}$. The ISs bromochloromethane and difluorobenzene were not used to quantitate the TICs because coeluting compounds appeared to have greatly altered the signal of the quantitation ions for those two ISs.

The ppbv concentrations are calculated from $\mathrm{mg} / \mathrm{m}^{3}$ and the molecular weight of the analyte. 


$$
\mathrm{TIC} \text { in ppbv }=\frac{\mathrm{TIC}\left(\mathrm{mg} / \mathrm{m}^{3}\right) \times 22.4 \mathrm{~L} / \mathrm{mol} \times 1000}{\text { TIC } \mathrm{g} \mathrm{mol} \mathrm{wt}}
$$

The IS level added to all blank, standard, and sample injections was $18.3 \mathrm{ppbv}$ for bromochloromethane, $20.3 \mathrm{ppbv}$ for 1,4-difluorobenzene, and $18.2 \mathrm{ppbv}$ for chlorobenzene- $\mathrm{d}_{5}$. The IS concentrations were converted from $\mathrm{ppbv}$ to $\mathrm{mg} / \mathrm{m}^{3}$ at STP using a molecular weight of 129.39 $(\mathrm{g} / \mathrm{mol})$ for bromochloromethane, 114.09 for 1,4-difluorobenzene, and 117.6 for chlorobenzene- $\mathrm{d}_{5}$.

\subsection{Analysis Results}

The results from the GC/MS analysis of the tank-headspace samples are presented in Tables 3.1 and 3.2. Results of the analysis of ambient air samples are presented in Table 3.3. A representative total ion chromatogram showing the identity of major constituents is given in Figure 3.1.

Table 3.1 lists the quantitative results for compounds listed in Method TO-14. Three target analytes were detected with trichlorofluoromethane (FREON 11) at the highest concentration of 0.73 $\mathrm{mg} / \mathrm{m}^{3}$.

Table 3.2 lists the semiquantitative results for the TICs observed in the samples. The predominant species observed in this sample were normal paraffin hydrocarbons (NPH), defined as nalkanes from $C_{11}$ to $C_{15}$. Dodecane had the highest concentration $\left(13.61 \mathrm{mg} / \mathrm{m}^{3}\right)$. It should be noted that because the SUMMA ${ }^{\mathrm{ti}}$ canisters were not heated at the time of analysis, the NPH concentrations listed after the retention time of decane may not be a true accounting of all the NPH in the sample. Similarly, polar compounds, which may adhere to the inside surface of the canister, may also be under represented in this analysis. The total concentration of the TIC compounds was found to be $83.87 \mathrm{mg} / \mathrm{m}^{3}$.

Table 3.3 lists the TIC and estimated concentrations for ambient air samples, one collected $\sim 10 \mathrm{~m}$ upwind and the other collected through the VSS positioned near Tank $\mathrm{C}-101$. Six compounds were detected upwind of Tank C-101 with butanal at the highest concentration $\left(0.45 \mathrm{mg} / \mathrm{m}^{3}\right)$. Three compounds were detected in the samples collected near the tank through the VSS with acetaldehyde at the highest concentration $\left(0.21 \mathrm{mg} / \mathrm{m}^{3}\right)$. No TO-14 target analytes were observed in the ambient air. 


\section{-}

- 


\subsection{Conclusions}

The concentrations of selected inorganic and organic compounds were determined from samples of the headspace of Tank C-101 on 9/1/94. Sampling and analysis methods followed those described by Ligotke et al. (1994) for samples obtained from C-103, a tank containing a relatively complex headspace composition. Method-validation measurements during that study did appear to validate the trapping and analysis of $\mathrm{NH}_{3}$, but did not eliminate the possibility of interferences that could affect $\mathrm{NO}_{\mathrm{x}}$ results. It is recommended that additional control samples be obtained if a tank is discovered in the future to contain significant quantities of $\mathrm{NO}_{\mathrm{x}}$. In the current sample job, $\mathrm{NO}_{\mathrm{x}}$ samples were obtained after first passing the sample flow through an $\mathrm{NH}_{3}$ trap. The $\mathrm{NH}_{3}$ concentration was found to be $98 \pm 1 \mathrm{ppmv}$. The concentration of $\mathrm{NO}_{2}$ was $\leq 0.04 \mathrm{ppmv}$. The concentration of $\mathrm{NO}$ was $1.5 \pm 0.1 \mathrm{ppmv}$. The mass concentration was $36 \pm 1 \mathrm{mg} / \mathrm{L}$, and was expected to consist largely of water vapor.

Organic analysis of the headspace samples from Tank C-101 identified three TO-14 target analyte compounds above the 2-ppbv detection limit and 120 TIC compounds above the 10-ppbv detection limit. The concentration of the total TO-14 target analytes accounted for less than $1 \%$ of the total compounds identified by organic analysis. For the TIC compounds, dodecane accounted for $16 \%$ of the total TIC concentration. The results of the TIC identified NPH-type compounds as the predominant species present. The TIC results of the ambient air samples, collected $\sim 10 \mathrm{~m}$ upwind of Tank C-101, identified six compounds, with butanal at the highest concentration. Three compounds were detected in the sample collected near the tank through the VSS, with acetaldehyde at the highest concentration. No TO-14 target analytes were observed in the ambient air sample. 


\subsection{References}

Clauss, T. W., M. W. Ligotke, B. D. McVeety, K. H. Pool, R. B. Lucke, J. S. Fruchter, and S. C. Goheen. 1994. Vapor Space Characterization of Waste Tank 241-by-104: Results from Samples Collected on 6/24/94. PNL-10208. Pacific; Northwest Laboratory, Richland, Washington.

Ligotke, M. W., K. H. Pool, and B. D. Lerner. 1994. Vapor Space Characterization of Waste Tank 241-C-103: Inorganic Results from Sample Job 7B (5/12/94). PNL-10172, Pacific Northwest Laboratory, Richland, Washington.

\subsection{Further Reading}

Pacific Northwest Laboratory. Analytical Laboratory Procedure Compendium. Procedures PNLALO-212, -226, -271. PNL-MA-599, Richland, Washington.

Pacific Northwest Laboratory. Quality Assurance Manual, Part 2: Good Practices Standard. PNLMA-70, Part 2, Richland, Washington.

Pacific Northwest Laboratory. Quality Assurance Plan for Activities Conducted by the Analytical Chemistry Laboratory (ACL). MCS-033, Analytical Chemistry Laboratory, Richland, Washington.

Pacific Northwest Laboratory. 1994. Determination of TO-14 Volatile Organic Compounds in Hanford Waste Tank Headspace Samples Using SUMMA" Passivated Canister Sampling and GAs Chromatographic-Mass Spectrometry Analysis, PNL-TVP-03 (Rev. 0), PNL Technical Procedure, Richland, Washington.

Pacific Northwest Laboratory. 1994. Sample Shipping and Receiving Procedure - DRAFT for PNL Waste Tank Samples. PNL-TVP-07 (Rev. 0), PNL Technical Procedure, Richland, Washington. 
Table 3.1 TO-14 Analysis for Samples from the Headspace of Tank C-101 in SUMMA ${ }^{\text {TM }}$ Canister Samples Collected on 9/1/94

\begin{tabular}{|c|c|c|c|c|c|c|c|c|c|c|}
\hline \multirow[b]{2}{*}{ TO-14 Analyte } & \multirow[b]{2}{*}{ CAS No. } & \multirow[b]{2}{*}{ Mol Wt } & \multicolumn{2}{|c|}{$\begin{array}{l}\text { S4056-A05-033 } \\
\text { PNL 033 } \\
\text { Concentration }\end{array}$} & \multicolumn{2}{|c|}{$\begin{array}{l}\text { S4056-A07-058 } \\
\text { PNL 058 } \\
\text { Concentration }\end{array}$} & \multicolumn{2}{|c|}{$\begin{array}{l}\text { S4056-A07-062 } \\
\text { PNL 062 } \\
\text { Concentration }\end{array}$} & \multicolumn{2}{|c|}{$\begin{array}{l}\text { Means and } \\
\text { Standard Deviations }\end{array}$} \\
\hline & & & $\left(\mathrm{mg} / \mathrm{m}^{3}\right)$ & (ppbv) & $\left(\mathrm{mg} / \mathrm{m}^{3}\right)$ & (ppbv) & $\left(\mathrm{mg} / \mathrm{m}^{3}\right)$ & (ppbv) & $\left(\mathrm{mg} / \mathrm{m}^{3}\right)$ & St Dev \\
\hline Dichlorodifluoromethane (FREON-12) & $75-71-8$ & 120 & $<0.01$ & $<2$ & $<0.01$ & $<2$ & $<0.01$ & $<2$ & (c) & (c) \\
\hline Methyl Chloride (Chloromethane) & 74-87-3 & 50 & $<0.01$ & $<2$ & $<0.01$ & $<2$ & $<0.01$ & $<2$ & (c) & (c) \\
\hline 1,2-Dichloro-1,1,2,2,-Tetrafluoroethane (FREON-114) & $76-14-2$ & 170 & $<0.02$ & $<2$ & $<0.02$ & $<2$ & $<0.02$ & $<2$ & (c) & (c) \\
\hline Chloroethene (Vinyl Chloride) & $75-01-4$ & 64 & $<0.01$ & $<2$ & $<0.01$ & $<2$ & $<0.01$ & $<2$ & (c) & (c) \\
\hline Methyl Bromide (Bromomethane) & $74-83-9$ & 94 & $<0.01$ & $<2$ & $<0.01$ & $<2$ & $<0.01$ & $<2$ & (c) & (c) \\
\hline Ethyl Chloride & $75-00-3$ & 62 & $<0.01$ & $<2$ & $<0.01$ & $<2$ & $<0.01$ & $<2$ & (c) & (c) \\
\hline Trichlorofluoromethane (FREON-11) & $75-69-4$ & 136 & 0.98 & 161 & 0.63 & 104 & 0.58 & 95.7 & 0.73 & 92.6 \\
\hline 1,1-Dichloroethene (1,1-Dichloroethylene) & $75-35-4$ & 96 & $<0.01$ & $<2$ & $<0.01$ & $<2$ & $<0.01$ & $<2$ & (c) & (c) \\
\hline Dichloromethane (Methylene Chloride) & $75-09-2$ & 84 & $<0.01$ & $<2$ & $<0.01$ & $<2$ & $<0.01$ & $<2$ & (c) & (c) \\
\hline 1,1,2-Trichloro-1,2,2-Trifluoroethane (FREON-113) & $76-13-1$ & 186 & $<0,02$ & $<2$ & $<0.02$ & $<2$ & $<0.02$ & $<2$ & (c) & (c) \\
\hline 1,1-Dichloroethane & $75-34-3$ & 98 & $<0.01$ & $<2$ & $<0.01$ & $<2$ & $<0.01$ & $<2$ & (c) & (c) \\
\hline cis-1,2-Dichloroethene (cis-1,2-Dichloroethylene) & $156-59-2$ & 96 & $<0.01$ & $<2$ & $<0.01$ & $<2$ & $<0.01$ & $<2$ & (c) & (c) \\
\hline Trichloromethane (Chloroform) & $67-66-3$ & 118 & $<0.01$ & $<2$ & $<0.01$ & $<2$ & $<0.01$ & $<2$ & (c) & (c) \\
\hline cis 1,2-Dichloroethane & $107-06-2$ & 98 & $<0.01$ & $<2$ & $<0.01$ & $<2$ & $<0.01$ & $<2$ & (c) & (c) \\
\hline 1,1,1-Trichloroethane & $71-55-6$ & 132 & $<0.01$ & $<2$ & $<0.01$ & $<2$ & $<0.01$ & $<2$ & (c) & (c) \\
\hline Benzene & $71-43-2$ & 78 & $<0.01$ & $<2$ & $<0.01$ & $<2$ & $<0.01$ & $<2$ & (c) & (c) \\
\hline Carbon Tetrachloride & $56-23-5$ & 152 & $<0.01$ & $<2$ & $<0.01$ & $<2$ & $<0.01$ & $<2$ & (c) & (c) \\
\hline 1,2-Dichloropropane & $78-87-5$ & 112 & $<0.01$ & $<2$ & $<0.01$ & $<2$ & $<0.01$ & $<2$ & (c) & (c) \\
\hline Trichloroethylene & $79-01-6$ & 130 & $<0.01$ & $<2$ & $<0.01$ & $<2$ & $<0.01$ & $<2$ & (c) & (c) \\
\hline cis 1,3-Dichloropropene & $61-01-5$ & 110 & $<0.01$ & $<2$ & $<0.01$ & $<2$ & $<0.01$ & $<2$ & (c) & (c) \\
\hline trans 1,3-Dichloropropene & $61-02-6$ & 110 & $<0.01$ & $<2$ & $<0.01$ & $<2$ & $<0.01$ & $<2$ & (c) & (c) \\
\hline 1,1,2-Trichloroethane & $79-00-5$ & 132 & $<0.01$ & $<2$ & $<0.01$ & $<2$ & $<0.01$ & $<2$ & (c) & (c) \\
\hline Methyl Benzene (Toluene) & $108-88-3$ & 92 & 0.05 & 11.5 & 0.05 & 11.5 & 0.04 & 10.6 & 0.05 & 6.61 \\
\hline 1,2-Dibromoethane & $106-93-4$ & 186 & $<0.02$ & $<2$ & $<0.02$ & $<2$ & $<0.02$ & $<2$ & (c) & (c) \\
\hline Tetrachloroethene (Perchloroethylene) & $127-18-4$ & 164 & 0.02 & 2.79 & 0.03 & 4.66 & 0.03 & 4.23 & 0.03 & 1.59 \\
\hline Chlorobenzene & $108-90-7$ & 112 & $<0.01$ & $<2$ & $<0.01$ & $<2$ & $<0.01$ & $<2$ & (c) & (c) \\
\hline Ethylbenzene & $100-41-4$ & 106 & $<0.01$ & $<2$ & $<0.01$ & $<2$ & $<0.01$ & $<2$ & (c) & (c) \\
\hline $\mathrm{m} \cdot$ Xylene (1,3-Dimethylbenzene) $^{(\mathrm{d})}$ & $108-38-3$ & 106 & $<0.01$ & $<2$ & $<0.01$ & $<2$ & $<0.01$ & $<2$ & (c) & (c) \\
\hline p-Xylene $(1,4 \text {-Dimethylbenzene })^{(d)}$ & $106-42-3$ & 106 & & & & & & & & \\
\hline Styrene & $100-42-5$ & 104 & $<0.01$ & $<2$ & $<0.01$ & $<2$ & $<0.01$ & $<2$ & (c) & (c) \\
\hline
\end{tabular}


Table $3.1 \quad$ (Contd)

\section{TO-14 Analve}

1,1,2,2-Tetrachloroethane

o-Xylene (1,2-Dimethylbenzene)

1,3,5-Trimethyibenzene

1,2,4-Trimethylbenzene

Chloromethylbenzene, alpha (Benzyl Chloride)

m-Dichlorobenzene (1,3-Dichlorobenzene)

p-Dichlorobenzene (1,4-Dichlorobenzene)

o-Dichlorobenzene (1,2-Dichlorobenzene)

1,2,4-Trichlorobenzene

Hexachloro-1,3-Butadiene

\begin{tabular}{|c|c|c|c|c|c|c|c|}
\hline \multirow[b]{2}{*}{ CAS No. } & \multirow[b]{2}{*}{ Mol Wt } & \multicolumn{2}{|c|}{$\begin{array}{l}\text { S4056-A05-033(a) } \\
\text { PNL 033 } \\
\text { Concentration } \\
\end{array}$} & \multicolumn{2}{|c|}{ 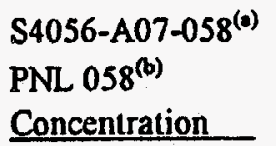 } & \multicolumn{2}{|c|}{$\begin{array}{l}\text { S4056-A07-062 } \\
\text { PNL 062 } \\
\text { Concentration } \\
\end{array}$} \\
\hline & & $\left(\mathrm{mg} / \mathrm{m}^{3}\right)$ & (ppbv) & $\left(\mathrm{mg} / \mathrm{m}^{3}\right)$ & (ppbv) & $\left(\mathrm{mg} / \mathrm{m}^{3}\right)$ & (ppbv) \\
\hline $79-34-5$ & 166 & $<0.02$ & $<2$ & $<0.02$ & $<2$ & $<0.02$ & $<2$ \\
\hline $95-47-6$ & 106 & $<0.01$ & $<2$ & $<0.01$ & $<2$ & $<0.01$ & $<2$ \\
\hline $108-67-8$ & 120 & $<0.01$ & $<2$ & $<0.01$ & $<2$ & $<0.01$ & $<2$ \\
\hline $95-63-6$ & 120 & $<0.01$ & $<2$ & $<0.01$ & $<2$ & $<0.01$ & $<2$ \\
\hline $100-44-7$ & 126 & $<0.01$ & $<2$ & $<0.01$ & $<2$ & $<0.01$ & $<2$ \\
\hline $541-73-1$ & 146 & $<0.01$ & $<2$ & $<0.01$ & $<2$ & $<0.01$ & $<2$ \\
\hline $106-46-7$ & 146 & $<0.01$ & $<2$ & $<0.01$ & $<2$ & $<0.01$ & $<2$ \\
\hline $95-50-1$ & 146 & $<0.01$ & $<2$ & $<0.01$ & $<2$ & $<0.01$ & $<2$ \\
\hline $120-82-1$ & 180 & $<0.02$ & $<2$ & $<0.02$ & $<2$ & $<0.02$ & $<2$ \\
\hline $87-68-3$ & 258 & $<0.02$ & $<2$ & $<0.02$ & $<2$ & $<0.02$ & $<2$ \\
\hline
\end{tabular}

Means and

Standard Deviations $\left(\mathrm{mg} / \mathrm{m}^{3}\right) \quad$ St Dev

(c) (c)

(c) (c)

(c) (c)

(c) (c)

(c) (c)

(c) (c)

(c) (c)

(c) (c)

(c) (c)

(c) (c)

O (a) WHC sample identification number.

(b) PNL canister number.

(c) Average and standard deviation data are not meaningful for this analyte.

(d) $\mathrm{m}$-Xylene and $\mathrm{p}$-Xylene coelute; the reported concentration is the sum of these two compounds. 
Table 3.2 Tentatively Identified Compounds and Estimated Concentrations ${ }^{(2)}$ from the Headspace of Tank C-101 in SUMMA ${ }^{\mathrm{TM}}$ Canister Samples Collected on 9/1/94

Tentatively

Identified Compound $^{(d)}$

Propene

Propane

Propyne

Cyclopropane

Acetaldehyde

Isobutane

1-Butene

Butane

2-Methyl-1-propene

Acetonitrile

N

Acetone
1-Pentene

Pentane

Methyl nitrate

Propanenitrile

2-Pentene

2-Pentanone

2-Methylpentane

Butanal

2-Butanone

1-Hexene

Tetrahydrofuran

2-Methyl-2-propanenitrile

Butanenitrile

3-Methyl-2-butanone

2-Pentanone

3-Methyl-2-butanone

1-Butanol

1-Methylethylnitrate

2-Pentanone

Pentanal

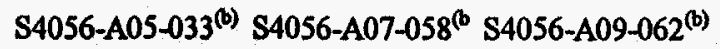

PNL 033 ${ }^{(\circ)} \quad$ PNL 058 $8^{(0)} \quad$ PNL 062 $2^{(0)}$

Concentration Concentration Concentration CAS No. ${ }^{(d)}$ Mol. Wt Ret Tim $\left(\mathrm{mg} / \mathrm{m}^{3}\right)$ (ppbv) $\frac{\left.\text { (mg/m }{ }^{3}\right) \text { (ppbv) }}{\left(\mathrm{mg} / \mathrm{m}^{3}\right) \text { (ppbv) }}$

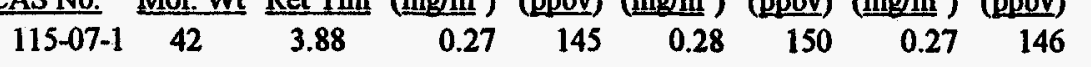

$\begin{array}{lllllllll}74-98-6 & 44 & 3.98 & 0.50 & 255 & 0.49 & 248 & 0.50 & 252\end{array}$

$\begin{array}{lllllllll}74-99-7 & 40 & 4.34 & 0.55 & 309 & 0.57 & 318 & 0.56 & 311\end{array}$

$75-19-4 \quad 42$

75-07-0 44

75-28-5 58

106-98-9 56

106-97-8 58

$115-11-7 \quad 56$

75-05-8 41

67-64-1 58

109-67-1 70

$109-66-0 \quad 72$

598-58-3 77

$107-12-0 \quad 55$

109-68-2 70

$107-87-9 \quad 86$

107-83-5 86

123-72-8 72

78-93-3 72

592-41-6 84

$109-99-9 \quad 72$

126-98-7 67

109-74-0 69

563-80-4 86

107-87-9 86

563-80-4 86

71-36-3 74

1712-64-7 105

$107-87-9 \quad 86$

$110-62-3 \quad 86$

$$
4.76
$$

5.09
5.10$$
5.77
$$

5.97

6.62

7.92

8.46

9.16

9.65

10.47

11.91

13.01

13.02

13.14

13.41

13.55

14.21

15.83

17.05

17.05

17.21

17.23

17.24

17.57

18.34

18.66

19.19 $\begin{array}{llllll}0.26 & 138 & 0.27 & 141 & 0.26 & 140\end{array}$

$<0.02<10.0<0.02<10.0 \quad 0.07 \quad 33.6$

$\begin{array}{llllll}0.06 & 23.9 & 0.06 & 23.2 & 0.07 & 25.9\end{array}$

$\begin{array}{lllllll}0.17 & 68.8 & 0.17 & 66.4 & 0.17 & 69.2\end{array}$

$\begin{array}{llllll}0.69 & 265 & 0.64 & 248 & 0.67 & 260\end{array}$

$\begin{array}{llllll}0.15 & 58.8 & 0.14 & 54.4 & 0.15 & 60.0\end{array}$

$\begin{array}{llllll}0.24 & 129 & 0.24 & 130 & 0.25 & 134\end{array}$

$\begin{array}{llllll}0.90 & 349 & 0.92 & 356 & 0.90 & 348\end{array}$

$\begin{array}{llllll}0.07 & 21.8 & <0.03<10.0 & 0.07 & 21.8\end{array}$

$\begin{array}{llllll}0.37 & 114 & 0.36 & 112 & 0.36 & 112\end{array}$

$\begin{array}{llllll}0.08 & 22.7 & 0.07 & 21.5 & 0.07 & 21.5\end{array}$

$<0.02<10.0 \quad 0.08 \quad 31.4<0.02<10.0$

$<0.03<10.0<0.03<10.0 \quad 0.07 \quad 21.4$

$<0.04<10.0<0.04<10.0<0.04<10.0$

$\begin{array}{llllll}0.24 & 61.5 & 0.24 & 62.5 & 0.24 & 62.8\end{array}$

$\begin{array}{lllllll}0.22 & 68.8 & 0.23 & 70.6 & 0.22 & 67.8\end{array}$

$\begin{array}{llllll}0.36 & 111 & 0.35 & 108 & 0.34 & 107\end{array}$

$\begin{array}{llllll}0.08 & 20.8 & 0.08 & 22.1 & 0.08 & 22\end{array}$

$\begin{array}{llllll}0.25 & 76.2 & 0.43 & 132 & 0.42 & 132\end{array}$

$<0.03<10.0<0.03<10.0 \quad 0.11 \quad 36.4$

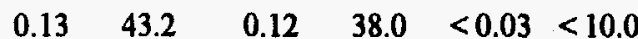

$\begin{array}{lllll}0.13 & 34.6 & 0.12 & 30.5 & <0.03<10.0\end{array}$

$<0.04<10.0<0.04<10.0 \quad 0.11 \quad 29.7$

$\begin{array}{lllll}0.13 & 34.6 & 0.12 & 30.5 & <0.04<10.0\end{array}$

$\begin{array}{llllll}0.76 & 229 & 0.87 & 264 & 0.61 & 183\end{array}$

$\begin{array}{llllll}0.16 & 33.7 & 0.14 & 30.3 & 0.14 & 29.0\end{array}$

$\begin{array}{llllll}0.67 & 174 & 0.58 & 151 & 0.56 & 145\end{array}$

$\begin{array}{lllllll}1.01 & 263 & 0.90 & 234 & 0.84 & 219\end{array}$
Means and

Standard Deviations

$\frac{\left(\mathrm{mg} / \mathrm{m}^{3}\right)}{0.28} \frac{\text { St Dev }}{0.01}(\mathrm{ppbv}) \frac{\mathrm{St} \mathrm{Dev}}{147}$

$\begin{array}{llll}0.28 & 0.01 & 147 & 2.8\end{array}$

$\begin{array}{llll}0.49 & 0.01 & 252 & 3.3\end{array}$

$\begin{array}{llll}0.56 & 0.01 & 313 & 4.3\end{array}$

$\begin{array}{llll}0.26 & 0.00 & 140 & 1.9\end{array}$

(e) (e)

$\begin{array}{llll}0.06 & 0.00 & 24.3 & 1.4\end{array}$

$\begin{array}{llll}0.17 & 0.00 & 68.1 & 1.5\end{array}$

$\begin{array}{llll}0.67 & 0.02 & 257 & 8.9\end{array}$

$\begin{array}{llll}0.14 & 0.01 & 57.7 & 2.9\end{array}$

$\begin{array}{llll}0.24 & 0.00 & 131 & 2.7\end{array}$

$\begin{array}{llll}0.91 & 0.01 & 351 & 4.3\end{array}$

$\begin{array}{lllll}0.07 & 0.00 & 21.8 & 0.0\end{array}$

$\begin{array}{llll}0.36 & 0.00 & 112 & 1.0\end{array}$

$\begin{array}{lllll}0.08 & 0.00 & 21.9 & 0.7\end{array}$

(e) (e)

(e) (e)

(e)

$\begin{array}{llll}0.24 & 0.00 & 62.3 & 0.7\end{array}$

$\begin{array}{llll}0.22 & 0.00 & 69.1 & 1.4\end{array}$

$\begin{array}{llll}0.35 & 0.01 & 109 & 2.1\end{array}$

$\begin{array}{llll}0.08 & 0.00 & 21.5 & 0.7\end{array}$

$\begin{array}{llll}0.36 & 0.10 & 113 & 32.2\end{array}$

(e) $\quad$ (e)

$\begin{array}{llll}0.13 & 0.01 & 40.6 & 3.7\end{array}$

$\begin{array}{llll}0.13 & 0.01 & 32.6 & 2.9\end{array}$

(e) (e)

$\begin{array}{llll}0.13 & 0.01 & 32.6 & 2.9\end{array}$

$\begin{array}{llll}0.75 & 0.13 & 226 & 40.5\end{array}$

$\begin{array}{llll}0.15 & 0.01 & 31.0 & 2.4\end{array}$

$\begin{array}{llll}0.60 & 0.06 & 157 & 15.3\end{array}$

$\begin{array}{llll}0.92 & 0.09 & 239 & 22.6\end{array}$ 
C101 Table 3.2 (Contd)

Tentatively

Identified Compound $^{(\text {() }}$

Heptane

Unknown C7 Alkane

Methylcyclohexane

2-Methyl-1-butanol

Unknown C7 Alkene/Cycloalkane

Unknown C3 Nitrate

Unknown C8 Alkane

2-Hexanone

Hexanal

Octane

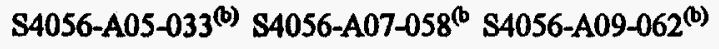

PNL 033 ${ }^{(\mathrm{o})} \quad$ PNL 058 ${ }^{(\mathrm{c})} \quad$ PNL 062 ${ }^{(\mathrm{c})}$

Concentration Concentration Concentration CAS No. ${ }^{(\mathrm{d})}$ Mol. Wt Ret Tim $\left(\mathrm{mg} / \mathrm{m}^{3}\right)$ (ppbv) $\left(\mathrm{mg} / \mathrm{m}^{3}\right) \quad(\mathrm{ppbv})\left(\mathrm{mg} / \mathrm{m}^{3}\right)$ (ppbv)

$\begin{array}{rrrrrrrrr}142-82-5 & 100 & 20.52 & 2.21 & 494 & 1.95 & 437 & 1.88 & 421 \\ & 100 & 21.74 & 0.27 & 60.5 & 0.26 & 58.5 & 0.23 & 51.5\end{array}$

$137-32-6-88-23.24$

$\begin{array}{llll}0.26 & 58.5 & 0.23 & 51.5\end{array}$

$\begin{array}{lllllll}0.14 & 31.8 & 0.13 & 29.7 & 0.13 & 29.3\end{array}$

$<0.04<10.0$

$0.16 \quad 41.2<0.04<10.0$

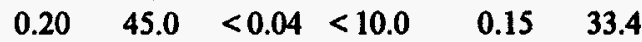

$\begin{array}{llllll}0.09 & 19.8 & 0.09 & 18.6 & 0.09 & 18.1\end{array}$

$\begin{array}{llllll}0.30 & 59.3 & 0.30 & 59.1 & 0.30 & 58.2\end{array}$

$\begin{array}{llllll}0.29 & 64.7 & 0.27 & 60.3 & 0.27 & 59.6\end{array}$

$\begin{array}{llllll}0.40 & 89.2 & 0.37 & 82.7 & 0.34 & 76.4\end{array}$

$\begin{array}{llllll}1.28 & 252 & 1.20 & 236 & 1.19 & 233\end{array}$

$<0.10<10.0 \quad 0.99 \quad 100<0.10<10.0$

$\begin{array}{llllll}0.10 & 22.4 & 0.10 & 22.4 & 0.09 & 21.0\end{array}$

$\begin{array}{llllll}0.16 & 28.7 & 0.16 & 28.0 & 0.16 & 27.1\end{array}$

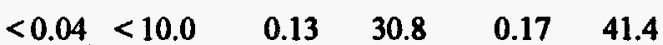

$0.09 \quad 15.2<0.06<10.0<0.06<10.0$

$\begin{array}{llllll}0.31 & 59.9 & 0.29 & 56.6 & 0.28 & 54.2\end{array}$

$\begin{array}{lllllll}0.13 & 29.3 & 0.20 & 45.7 & 0.19 & 43.0\end{array}$

$\begin{array}{lllllll}0.32 & 62.3 & 0.32 & 61.9 & 0.29 & 57.8\end{array}$

$\begin{array}{llllll}0.61 & 107 & 0.60 & 104 & 0.57 & 98.9\end{array}$

$\begin{array}{llllll}0.12 & 19.9 & 0.12 & 19.7 & 0.11 & 18.9\end{array}$

$\begin{array}{llllll}0.63 & 110 & 0.60 & 105 & 0.57 & 100\end{array}$

$<0.06<10.0<0.06<10.0 \quad 0.09 \quad 14.2$

$\begin{array}{rrrrrr}0.09 & 14.9 & 0.10 & 15.4 & <0.06<10.0\end{array}$

$\begin{array}{llllll}0.16 & 28.4 & 0.16 & 28.0 & 0.16 & 27.5\end{array}$

$\begin{array}{llllll}0.10 & 15.7 & 0.09 & 14.4 & <0.06<10.0\end{array}$

$0.20 \quad 35.2<0.06<10.0 \quad 0.23 \quad 40.4$

$<0.13<10.0 \quad .0 .39 \quad 29.1<0.13<10.0$

$\begin{array}{lllll}0.10 & \text { (f) } & 0.10 & \text { (f) }\end{array}$

$\begin{array}{llllll}1.52 & 240 & 1.43 & 225 & 1.43 & 225\end{array}$

$\begin{array}{llllll}0.09 & 13.0 & 0.09 & 13.3 & 0.09 & 13.1\end{array}$

$\begin{array}{llllll}0.50 & 71.8 & 0.50 & 72.2 & 0.52 & 74.5\end{array}$

$\begin{array}{rrr}2847-72-5 & 156 & 36.97\end{array}$
Means and

Standard Deviations

$\frac{\left.\mathrm{mg} / \mathrm{m}^{3}\right)}{2.01} \frac{\mathrm{St} \mathrm{Dev}}{\mathbf{0 . 1 7}} \quad \frac{\mathrm{ppbv})}{451} \frac{\mathrm{St} \mathrm{Dev}}{38.6}$

$\begin{array}{llll}0.25 & 0.02 & 56.8 & 4.7\end{array}$

$\begin{array}{llll}0.13 & 0.01 & 30.2 & 1.3\end{array}$

(e) (e)

$\begin{array}{llll}0.17 & 0.04 & 39.2 & 8.2\end{array}$

$\begin{array}{lllll}0.09 & 0.00 & 18.8 & 0.9\end{array}$

$\begin{array}{lllll}0.30 & 0.00 & 58.9 & 0.6\end{array}$

$\begin{array}{lllll}0.27 & 0.01 & 61.5 & 2.8\end{array}$

$\begin{array}{lllll}0.37 & 0.03 & 82.7 & 6.4\end{array}$

$\begin{array}{llll}1.22 & 0.05 & 240 & 10.0\end{array}$

(e) (e)

$\begin{array}{llll}0.10 & 0.00 & 21.9 & 0.8\end{array}$

$\begin{array}{llll}0.16 & 0.00 & 27.9 & 0.8\end{array}$

$\begin{array}{llll}0.15 & 0.03 & 36.1 & 7.5\end{array}$

(e) (e)

$\begin{array}{llll}0.29 & 0.01 & 56.9 & 2.9\end{array}$

$\begin{array}{lllll}0.17 & 0.04 & 39.3 & 8.8\end{array}$

$\begin{array}{lllll}0.31 & 0.01 & 60.7 & 2.5\end{array}$

$\begin{array}{llll}0.59 & 0.02 & 104 & 4.3\end{array}$

$\begin{array}{llll}0.12 & 0.00 & 19.5 & 0.5\end{array}$

$\begin{array}{llll}0.60 & 0.03 & 105 & 5.2\end{array}$

(e) (e)

$\begin{array}{llll}0.09 & 0.00 & 15.1 & 0.3\end{array}$

$\begin{array}{llll}0.16 & 0.00 & 27.9 & 0.4\end{array}$

$\begin{array}{llll}0.09 & 0.01 & 15.0 & 0.9\end{array}$

$\begin{array}{llll}0.22 & 0.02 & 37.8 & 3.7\end{array}$

(e) (e)

$\begin{array}{ll}0.10 & 0.00\end{array}$

$\begin{array}{lllll}1.46 & 0.05 & 230 & 8.7\end{array}$

$\begin{array}{llll}0.09 & 0.00 & 13.1 & 0.2\end{array}$

$\begin{array}{llll}0.51 & 0.01 & 72.8 & 1.5\end{array}$

Hexane Nitrate 
C101 Table $3.2 \quad$ (Contd)

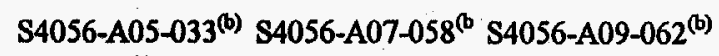
PNL 033 ${ }^{(\mathrm{c})} \quad$ PNL 058 ${ }^{(\mathrm{c})} \quad$ PNL 062 ${ }^{(\mathrm{c})}$

Tentatively

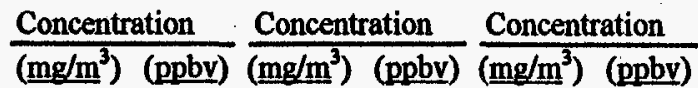

Identified Compound ${ }^{(d)}$

Unknown C10 Alkene/Cycloalkane Unknown C10 Alkene/Cycloalkane

Unknown C11 Alkene/Cycloalkane

Unknown C11 Alkane

Unknown C12 Alkane

Unknown C11 Alkene/Cycloalkane

Unknown C11 Alkane

trans-Decahydronaphthalene

Unknown C12 Alkene/Cycloalkane

Unknown C11 Alkene/Cycloalkane

Undecane

Unknown Alkene/Cycloalkane

Unknown C12 Alkane

Unknown C12 Alkane

2-Methyldecahydronaphthalene

Pentylcyclohexane

Unknown C12 Alkane

Unknown C12 Alkane

Unknown C13 Alkane

Unknown C12 Alkane

Unknown C12 Alkene/Cycloalkane

Unknown C12 Alkene/Cycloalkane

Unknown C13 Alkane

Dodecane

et Tim

0.10 (ppbv)

(mg/m (ppbv)

$\begin{array}{rr}\left(\mathrm{mg} / \mathrm{m}^{3}\right) & (\mathrm{ppbv}) \\ 0.10 & 16.3\end{array}$

CAS No. ${ }^{(d)} \frac{\mathrm{Mol} . \mathrm{Wt}}{140}$

37.36

$0.19 \quad 29.9$

$0.19 \quad 29.9$

$0.18 \quad 29.3$

38.14

38.42

$0.09 \quad 13.5$

$\begin{array}{ll}0.18 & 29.3 \\ 0.10 & 14.3\end{array}$

$0.09 \quad 13.4$

38.73

38.91

$0.11 \quad 15.0$

$0.08 \quad 119$

$\begin{array}{ll}0.09 & 12.5\end{array}$

$\begin{array}{ll}0.11 & 16.1\end{array}$

$0.11 \quad 14.4$

$0.11 \quad 14.6$

$156 \quad 39.05$

$0.16 \quad 22.5$

$\begin{array}{ll}0.11 & 16.0\end{array}$

39.42

$0.14 \quad 23.2$

$0.15 \quad 21.5$

$\begin{array}{ll}0.11 & 16.4\end{array}$

493-02-7 138

39.69

$168 \quad 40.00$

$0.13 \quad 18.9$

0.1722 .5

1120-21-4 156

40.22

40.75

41.02

41.47

41.85

42.26

42.49

42.70

42.87

43.17

43.33

43.59

44.01

44.34
44.52

Unknown C12 Alkene/Cycloalkane

$112-40-3 \quad 170$

44.74

2,6-Dimethyldecahydronaphthalen 1618-22-0 166

Unknown C13 Alkane

44.90

45.22

Unknown C13 Alkane

Unknown C13 Alkane

Unknown

Unknown C2 Decahydronaphthalene

45.41

45.52

$7.06 \quad 1013$
0.32

$\begin{array}{lll}0.32 & 43.1\end{array}$

$\begin{array}{ll}0.38 & 49.8\end{array}$

$\begin{array}{ll}0.50 & 66.1\end{array}$

$0.27 \quad 39.6$

$0.66 \quad 96.3$

$1.52 \quad 200$

$\begin{array}{ll}0.70 & 92.1\end{array}$

$1.43 \quad 174$

$0.91 \quad 120$

$0.21 \quad 28.5$

$0.19 \quad 25.1$

$1.49 \quad 182$

$15.22 \quad 2005$

$0.14 \quad 22.6$

$\begin{array}{ll}0.15 & 21.0\end{array}$

$\begin{array}{lllll}0.15 & 19.9 & 0.18 & 24.5\end{array}$

$6.26 \quad 898$

$\begin{array}{ll}0.31 & 41.3\end{array}$

$\begin{array}{ll}0.36 & 46.9\end{array}$

$6.05 \quad 869$

$\begin{array}{ll}0.30 & 39.7\end{array}$

$\begin{array}{llll}0.47 & 61.9 & 0.45 & 59.2\end{array}$

$\begin{array}{llll}0.35 & 50.8 & 0.37 & 53.8\end{array}$

$0.62 \quad 89.9$

$0.44 \quad 64.0$

$\begin{array}{ll}1.42 \quad 188 \\ 0.61 & 80.1\end{array}$

$\begin{array}{rr}0.61 & 80.1 \\ 1.32 & 160\end{array}$

$0.84 \quad 110$

$\begin{array}{ll}0.42 & 54.9\end{array}$

$0.84 \quad 110$

$0.21 \quad 27.3$

\begin{tabular}{lll}
11.3 & 0.20 & 27.2 \\
\hline
\end{tabular}

$\begin{array}{llll}0.17 & 22.8 & 0.16 & 20.9\end{array}$

$\begin{array}{lll}182 & 13.10 & 169\end{array}$

$0.6282 .7<0.08<10.0$

$1.27 \quad 155$

$\begin{array}{llll}6.59 & 803 & 5.49 & 668\end{array}$

$0.48 \quad 64.1$

$\begin{array}{llllll}1.07 & 131 & 1.01 & 123 & 0.96 & 117\end{array}$

$\begin{array}{llllll}0.26 & 32.0 & 0.21 & 25.4 & 0.19 & 23.4\end{array}$

45.95

0.25

(f)

$0.22 \quad$ (f)

$0.22 \quad$ (f)

\begin{tabular}{|c|c|c|c|}
\hline \multicolumn{4}{|c|}{$\begin{array}{l}\text { Means and } \\
\text { Standard Deviations }\end{array}$} \\
\hline$\left(\mathrm{mg} / \mathrm{m}^{3}\right)$ & St Dev & (ppbv) & St Dev \\
\hline 0.10 & 0.00 & 16.5 & 0.2 \\
\hline 0.19 & 0.00 & 29.7 & 0.4 \\
\hline 0.10 & 0.01 & 14.7 & 1.4 \\
\hline 0.09 & 0.01 & 12.6 & 0.7 \\
\hline 0.11 & 0.00 & 14.7 & 0.3 \\
\hline 0.11 & 0.00 & 16.2 & 0.2 \\
\hline 0.15 & 0.01 & 21.7 & 0.8 \\
\hline 0.14 & 0.01 & 21.9 & 1.7 \\
\hline 0.16 & 0.02 & 22.7 & 3.4 \\
\hline 0.17 & 0.02 & 22.3 & 2.3 \\
\hline 6.45 & 0.53 & 927 & 76.1 \\
\hline 0.31 & 0.01 & 41.4 & 1.7 \\
\hline 0.36 & 0.02 & 47.3 & 2.4 \\
\hline 0.47 & 0.03 & 62.4 & 3.5 \\
\hline 0.33 & 0.05 & 48.1 & 7.5 \\
\hline 0.57 & 0.12 & 83.4 & 17.1 \\
\hline 1.26 & 0.37 & 166 & 48.7 \\
\hline 0.57 & 0.14 & 75.7 & 19.0 \\
\hline 1.30 & 0.14 & 158 & 16.6 \\
\hline 0.84 & 0.08 & 110 & 9.9 \\
\hline 0.21 & 0.01 & 27.7 & 0.7 \\
\hline 0.17 & 0.02 & 22.9 & 2.1 \\
\hline 1.38 & 0.11 & 169 & 13.4 \\
\hline 13.61 & 1.42 & 1793 & 187.8 \\
\hline 0.55 & 0.10 & 73.4 & 13.1 \\
\hline 0.83 & 0.03 & 112 & 3.9 \\
\hline 5.70 & 0.81 & 693 & 98.9 \\
\hline 1.01 & 0.06 & 123 & 7.0 \\
\hline 0.22 & 0.04 & 26.9 & 4.5 \\
\hline 0.23 & 0.02 & & \\
\hline 1.21 & 0.08 & 163 & 10.7 \\
\hline
\end{tabular}


C101 Table $3.2 \quad$ (Contd)

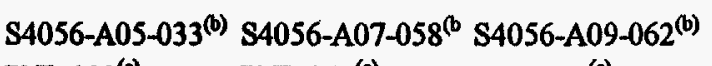

PNL 033 ${ }^{\left({ }^{\circ}\right)} \quad$ PNL 058 $8^{(\mathrm{o})} \quad$ PNL 062 $2^{(\mathrm{o})}$

Tentatively

Concentration Concentration Concentration

Identified Compound ${ }^{(d)}$

$\frac{\left.\mathrm{mg} / \mathrm{m}^{3}\right)(\mathrm{ppbv})}{\left(\mathrm{mg} / \mathrm{m}^{3}\right)(\mathrm{ppbv})} \frac{\left.\mathrm{mg} / \mathrm{m}^{3}\right)(\mathrm{ppbv})}{\left(\mathrm{m} / \mathrm{m}^{2}\right.}$

Unknown C3 Alkene/Cycloalkane

CAS No. $^{(\mathrm{d})} \frac{\text { Mol. Wt }}{182} \frac{\text { Ret Tim }}{46.30}$

4.42

Unknown C2 Alkyl Decahydronaphthalene

46.56

1.63

$\begin{array}{rr}3.95 & (\mathrm{mpbv}) \\ 486\end{array}$

$\begin{array}{rr}3.79 & (\mathrm{ppbv}) \\ 467 & (1.75)\end{array}$

Unknown C13 Alkane

$184 \quad 46.74$

Unknown C2 Decahydronaphthalene

166

46.88

$\begin{array}{llll}1.65 & 201 & 1.20 & 146\end{array}$

$1.45 \quad 195$

Unknown Alkane

47.02

$0.41 \quad 54.9<0.07<10.0$

$1.40 \quad 170$

7-Methyltridecane

26730-14-3 198

47.17

1.02

(f) $\begin{array}{rrr}<0.94 & <10.0 \\ \text { (f) }\end{array}$

$0.34 \quad 46.3$

Unknown Alkene/Cycloalkane

Tridecane

47.61

5.81

$\begin{array}{lll}658 & 4.99 & 564\end{array}$

0.95

$\begin{array}{llll}1.11 & \text { (f) } & 1.04 & \text { (f) } 0.86\end{array}$

Unknown Alkene/Cycloalkane

$629-50-5 \quad 184$

48.05

7.66

$\begin{array}{llll}933 & 6.48 & 788 & 6.98\end{array}$

Unknown Alkane

Unknown Alkene/Cycloalkane

Unknown C12 Ketone

48.43
48.77

2.00
0.66

(1)

49.05

3-Dodecanone

$184 \quad 50.20$

0.44

Unknown Alkane

$50.20 \quad 0.90$

Unknown

50.73
50.89

0.12

0.52

51.17

Tetradecane

$\begin{array}{lll}629-59-4 & 198 \quad 51.53\end{array}$

Unknown Alkene/Cycloalkane

0.43
0.12

0.12
0.17

(f) 1.87

$\begin{array}{lll}1.87 & \text { (f) } & 1.74 \\ 0.56 & \text { (f) } & 0.63\end{array}$

(f)

$\begin{array}{lllll}109 & 0.84 & 102 & 1.68 & 204\end{array}$

$\begin{array}{lllll}14.4 & 0.13 & 15.2 & 0.14 & 17.3\end{array}$

$\begin{array}{llll}\text { (f) } 0.50 & \text { (f) } 0.65 & \text { (f) }\end{array}$

(f) 0.40 (f) 0.42

$\begin{array}{llrrr}13.1 & 0.13 & 14.6 & 0.27 & 30.3\end{array}$

(f)

0.14

(f)

0.18 (f)

Means and

Standard Deviations

(mg/m $\mathrm{m}^{3}$ St Dev (ppbv) St Dev

$\begin{array}{llll}4.05 & 0.33 & 499 & 40.1\end{array}$

$\begin{array}{llll}1.46 & 0.16 & 197 & 21.8\end{array}$

$\begin{array}{llll}1.42 & 0.22 & 172 & 27.4\end{array}$

$\begin{array}{llll}0.38 & 0.05 & 50.6 & 6.1\end{array}$

$0.94 \quad 0.09$

$5.28 \quad 0.47$

$1.00 \quad 0.13$

$7.04 \quad 0.60$

$1.87 \quad 0.13$

0.610 .05

(e)

$\begin{array}{llll}1.14 & 0.47 & 139 & 57.0\end{array}$

$\begin{array}{llll}0.13 & 0.01 & 15.6 & 1.5\end{array}$

$0.56 \quad 0.08$

$0.42 \quad 0.02$

$0.17 \quad 0.08$

$\begin{array}{ll}0.16 & 0.02\end{array}$

(a) Semi-quantitative estimate calculated using concentration of closest eluting internal standard.

(b) WHC sample identification number.

(c) PNL SUMMA ${ }^{\text {TM }}$ canister number.

(d) Obtained by mass spectral interpretation amd comparison with the EPA/NIST/WILEY Library.

(e) Average and standard deviation are not meaningful for this analyte.

(f) No molecular weight available for calculation. 
Table 3.3 Tentavtively Identified Compounds and Estimated Concentrations ${ }^{(a)}$ for Ambient Air Collected Near Tank C-101 in SUMMA ${ }^{\text {TM }}$ Canisters on 9/1/94

\begin{tabular}{|c|c|c|c|c|c|c|}
\hline \multirow[b]{2}{*}{ CAS No. ${ }^{(d)}$} & \multirow[b]{2}{*}{ Mol. Wt } & \multirow[b]{2}{*}{ Ret Time } & \multicolumn{2}{|c|}{$\begin{array}{l}\text { Upwind } \\
\text { S4056-A01-026 } \\
\text { PNL } 026^{(0)} \\
\text { Concentration }\end{array}$} & \multicolumn{2}{|c|}{$\begin{array}{l}\text { Through VSS } \\
\text { S4056-A02-031 } \\
\text { PNL } 031^{(0)} \\
\text { Concentration }\end{array}$} \\
\hline & & & $(\mathrm{mg} / \mathrm{m} 3)$ & $\overline{(p p b v)}$ & $\left(\mathrm{mg} / \mathrm{m}^{3}\right)$ & $\overline{(\mathrm{ppbv})}$ \\
\hline $75-07-0$ & 44 & 5.09 & 0.212 & 108 & 0.21 & 106 \\
\hline $67-64-1$ & 58 & 8.46 & 0.15 & 57.9 & 0.17 & 64.5 \\
\hline $78-94-4$ & 70 & 12.95 & 0.65 & 208 & $<0.03$ & $<10.0$ \\
\hline $107-87-9$ & 86 & 13.02 & $<0.04$ & $<10.0$ & 0.08 & 19.5 \\
\hline $123-72-8$ & 72 & 13.41 & 0.449 & 140 & $<0.03$ & $<10.0$ \\
\hline $78-93-3$ & 72 & 13.55 & 0.066 & 20.5 & $<0.03$ & $<10.0$ \\
\hline $71-36-3$ & 74 & 17.57 & 0.058 & 17.6 & $<0.03$ & $<10.0$ \\
\hline
\end{tabular}

(a) Semi-quantitative estimate calculated using concentration of closest eluting internal standard.

(b) WHC sample identification number.

(c) PNL SUMMA ${ }^{\mathrm{TM}}$ canister number.

(d) Obtained by mass spectral interpretation amd comparison with the EPA/NIST/WILEY Library. 


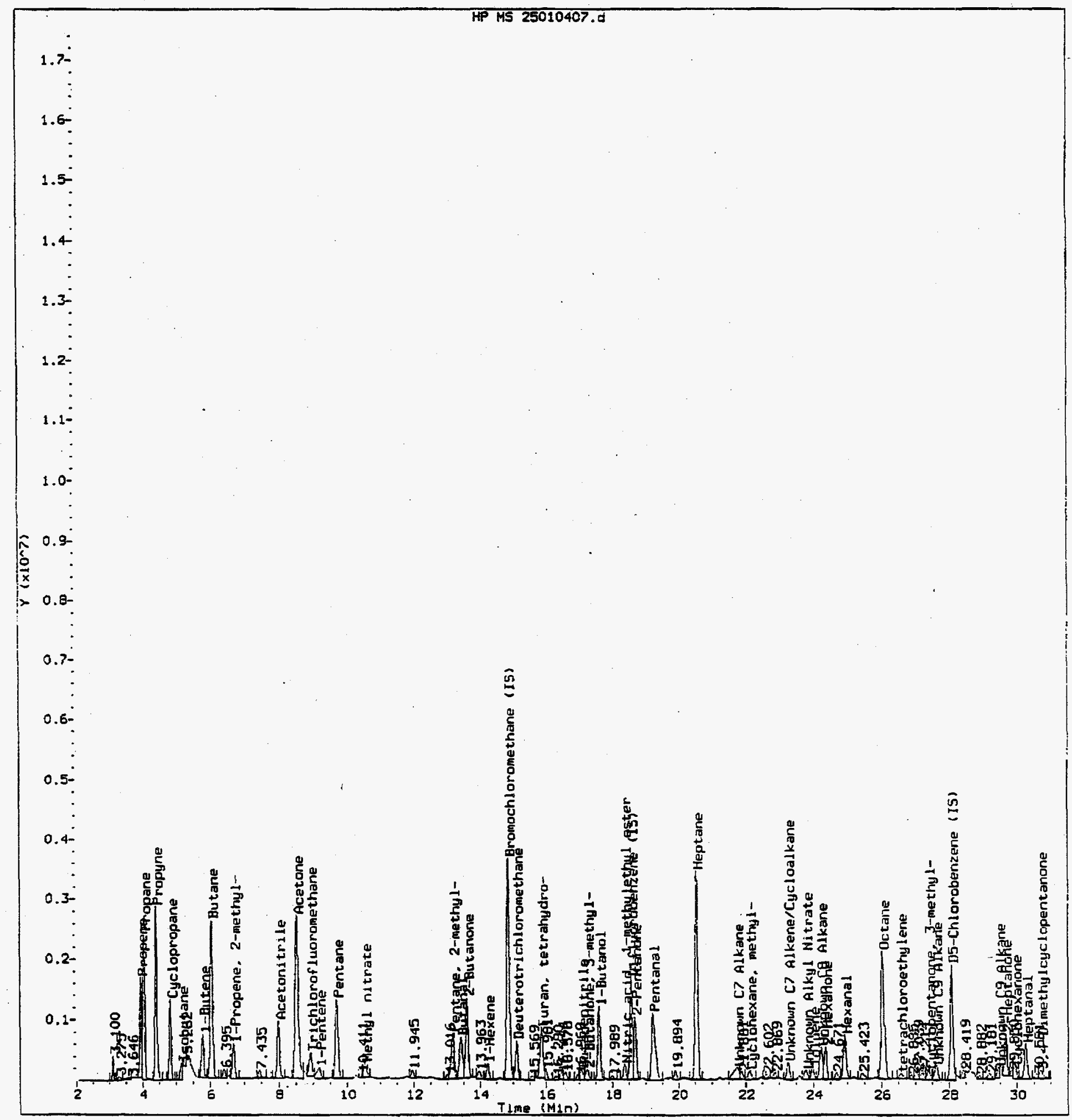

Figure 3.1a Total Ion Chromatogram ( 2 through $30 \mathrm{~min}$ ) for Hanford Waste Tank C-101 SUMMATM Canister Sample S4056-A05-033 Collected on 9/1/94 


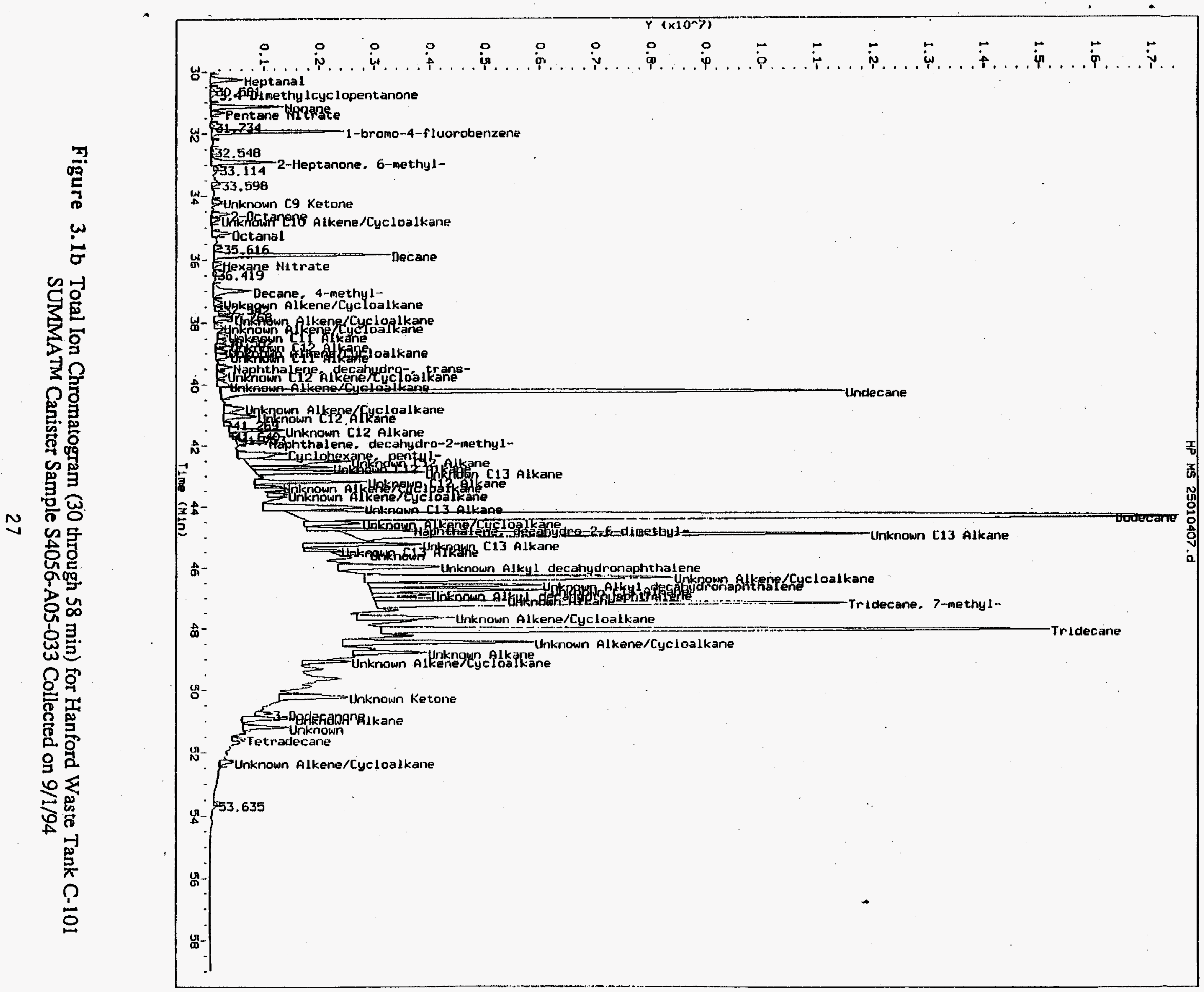

